\title{
Greenhouse gas emissions from natural ecosystems and agricultural lands in sub-Saharan Africa: synthesis of available data and suggestions for further research
}

\author{
Dong-Gill Kim ${ }^{1}$, Andrew D. Thomas ${ }^{2}$, David Pelster ${ }^{3}$, Todd S. Rosenstock ${ }^{4}$, and Alberto Sanz-Cobena ${ }^{5}$ \\ ${ }^{1}$ Wondo Genet College of Forestry and Natural Resources, Hawassa University, P.O. Box 128, Shashemene, Ethiopia \\ ${ }^{2}$ Department of Geography and Earth Sciences, Aberystwyth University, Aberystwyth SY23 3DB, UK \\ ${ }^{3}$ International Livestock Research Institute, P.O. Box 30709, Nairobi, Kenya \\ ${ }^{4}$ World Agroforestry Centre (ICRAF), P.O. Box 30677-00100, United Nations Avenue, Nairobi, Kenya \\ ${ }^{5}$ Technical University of Madrid, School of Agriculture, Avd. Complutense s/n, 28040 Madrid, Spain
}

Correspondence to: Dong-Gill Kim (donggillkim@gmail.com)

Received: 6 September 2015 - Published in Biogeosciences Discuss.: 9 October 2015

Revised: 23 July 2016 - Accepted: 3 August 2016 - Published: 29 August 2016

\begin{abstract}
This paper summarizes currently available data on greenhouse gas (GHG) emissions from African natural ecosystems and agricultural lands. The available data are used to synthesize current understanding of the drivers of change in GHG emissions, outline the knowledge gaps, and suggest future directions and strategies for $\mathrm{GHG}$ emission research. GHG emission data were collected from 75 studies conducted in 22 countries $(n=244)$ in sub-Saharan Africa (SSA). Carbon dioxide $\left(\mathrm{CO}_{2}\right)$ emissions were by far the largest contributor to GHG emissions and global warming potential (GWP) in SSA natural terrestrial systems. $\mathrm{CO}_{2}$ emissions ranged from 3.3 to $57.0 \mathrm{MgCO}_{2} \mathrm{ha}^{-1} \mathrm{yr}^{-1}$, methane $\left(\mathrm{CH}_{4}\right)$ emissions ranged from -4.8 to $3.5 \mathrm{~kg} \mathrm{ha}^{-1} \mathrm{yr}^{-1}$ ( -0.16 to $0.12 \mathrm{MgCO}_{2}$ equivalent (eq.) ha $\mathrm{hr}^{-1} \mathrm{yr}^{-1}$ ), and nitrous oxide $\left(\mathrm{N}_{2} \mathrm{O}\right)$ emissions ranged from -0.1 to $13.7 \mathrm{~kg} \mathrm{ha}^{-1} \mathrm{yr}^{-1}$ (-0.03 to $4.1 \mathrm{MgCO}_{2}$ eq. ha $\left.{ }^{-1} \mathrm{yr}^{-1}\right)$. Soil physical and chemical properties, rewetting, vegetation type, forest management, and land-use changes were all found to be important factors affecting soil GHG emissions from natural terrestrial systems. In aquatic systems, $\mathrm{CO}_{2}$ was the largest contributor to total $\mathrm{GHG}$ emissions, ranging from 5.7 to $232.0 \mathrm{MgCO}_{2} \mathrm{ha}^{-1} \mathrm{yr}^{-1}$, followed by -26.3 to $2741.9 \mathrm{~kg} \mathrm{CH}_{4} \mathrm{ha}^{-1} \mathrm{yr}^{-1}(-0.89$ to 93.2 $\mathrm{Mg} \mathrm{CO}_{2}$ eq. ha ${ }^{-1} \mathrm{yr}^{-1}$ ) and 0.2 to $3.5 \mathrm{~kg} \mathrm{~N}_{2} \mathrm{O} \mathrm{ha}^{-1} \mathrm{yr}^{-1}$ ( 0.06 to $1.0 \mathrm{Mg} \mathrm{CO}_{2}$ eq. ha ${ }^{-1} \mathrm{yr}^{-1}$ ). Rates of all GHG emissions from aquatic systems were affected by type, location,
\end{abstract}

hydrological characteristics, and water quality. In croplands, soil GHG emissions were also dominated by $\mathrm{CO}_{2}$, ranging from 1.7 to $141.2 \mathrm{MgCO}_{2} \mathrm{ha}^{-1} \mathrm{yr}^{-1}$, with -1.3 to $66.7 \mathrm{~kg} \mathrm{CH}_{4} \mathrm{ha}^{-1} \mathrm{yr}^{-1}$ (-0.04 to $2.3 \mathrm{Mg} \mathrm{CO}_{2}$ eq. ha ${ }^{-1} \mathrm{yr}^{-1}$ ) and 0.05 to $112.0 \mathrm{~kg} \mathrm{~N}_{2} \mathrm{O} \mathrm{ha}^{-1} \mathrm{yr}^{-1} \quad(0.015$ to 33. $4 \mathrm{Mg} \mathrm{CO}_{2}$ eq. $\mathrm{ha}^{-1} \mathrm{yr}^{-1}$ ). $\mathrm{N}_{2} \mathrm{O}$ emission factors (EFs) ranged from 0.01 to $4.1 \%$. Incorporation of crop residues or manure with inorganic fertilizers invariably resulted in significant changes in GHG emissions, but results were inconsistent as the magnitude and direction of changes were differed by gas. Soil GHG emissions from vegetable gardens ranged from 73.3 to $132.0 \mathrm{MgCO}_{2} \mathrm{ha}^{-1} \mathrm{yr}^{-1}$ and 53.4 to $177.6 \mathrm{~kg} \mathrm{~N}_{2} \mathrm{O} \mathrm{ha}^{-1} \mathrm{yr}^{-1} \quad(15.9$ to 52.9 $\mathrm{Mg} \mathrm{CO}_{2}$ eq. $\mathrm{ha}^{-1} \mathrm{yr}^{-1}$ ) and $\mathrm{N}_{2} \mathrm{O}$ EFs ranged from 3 to $4 \%$. Soil $\mathrm{CO}_{2}$ and $\mathrm{N}_{2} \mathrm{O}$ emissions from agroforestry were $38.6 \mathrm{Mg} \mathrm{CO}_{2} \mathrm{ha}^{-1} \mathrm{yr}^{-1}$ and 0.2 to $26.7 \mathrm{~kg} \mathrm{~N}_{2} \mathrm{O} \mathrm{ha}^{-1} \mathrm{yr}^{-1}$ (0.06 to $8.0 \mathrm{Mg} \mathrm{CO}_{2}$ eq. $\mathrm{ha}^{-1} \mathrm{yr}^{-1}$ ), respectively. Improving fallow with nitrogen $(\mathrm{N})$-fixing trees led to increased $\mathrm{CO}_{2}$ and $\mathrm{N}_{2} \mathrm{O}$ emissions compared to conventional croplands. The type and quality of plant residue in the fallow is an important control on how $\mathrm{CO}_{2}$ and $\mathrm{N}_{2} \mathrm{O}$ emissions are affected. Throughout agricultural lands, $\mathrm{N}_{2} \mathrm{O}$ emissions slowly increased with $\mathrm{N}$ inputs below $150 \mathrm{~kg} \mathrm{Nha}^{-1} \mathrm{yr}^{-1}$ and increased exponentially with $\mathrm{N}$ application rates up to $300 \mathrm{~kg} \mathrm{~N} \mathrm{ha}^{-1} \mathrm{yr}^{-1}$. The lowest yield-scaled $\mathrm{N}_{2} \mathrm{O}$ emissions were reported with $\mathrm{N}$ application rates ranging between 100 and $150 \mathrm{~kg} \mathrm{Nha}^{-1}$. Overall, total $\mathrm{CO}_{2}$ eq. emissions 
from SSA natural ecosystems and agricultural lands were $56.9 \pm 12.7 \times 10^{9} \mathrm{MgCO}_{2}$ eq. $\mathrm{yr}^{-1}$ with natural ecosystems and agricultural lands contributing 76.3 and $23.7 \%$, respectively. Additional GHG emission measurements are urgently required to reduce uncertainty on annual GHG emissions from the different land uses and identify major control factors and mitigation options for low-emission development. A common strategy for addressing this data gap may include identifying priorities for data acquisition, utilizing appropriate technologies, and involving international networks and collaboration.

\section{Introduction}

Global greenhouse gas (GHG) emissions were estimated to be $49 \times 10^{9} \mathrm{MgCO}_{2}$ eq. in 2010 (IPCC, 2014), with approximately $21.2-24 \%\left(10.3-12 \times 10^{9} \mathrm{Mg} \mathrm{CO}_{2}\right.$ eq. $)$ of emissions originating from soils in agricultural, forestry and other land use (AFOLU; Tubiello et al., 2015; IPCC, 2014). Annual non- $\mathrm{CO}_{2}$ GHG emissions (primarily $\mathrm{CH}_{4}$ and $\mathrm{N}_{2} \mathrm{O}$ ) from agriculture were estimated to be $5.2-5.8 \times 10^{9} \mathrm{MgCO}_{2}$ eq. $\mathrm{yr}^{-1}$ in 2010 (FAOSTAT, 2015; Tubiello et al., 2013), with approximately 4.3$5.5 \times 10^{9} \mathrm{MgCO}_{2}$ eq. $\mathrm{yr}^{-1}$ attributable to land-use change (IPCC, 2014).

Greenhouse gas fluxes in Africa play an important role in the global GHG budget (Thompson et al., 2014; Hickman et al., 2014; Valentini et al., 2014; Ciais et al., 2011; Bombelli et al., 2009). For example, $\mathrm{CO}_{2}$ eq. emissions from 12 river channels in SSA and wetlands of the Congo River were $3.3 \times 10^{9} \mathrm{MgCO}_{2}$ eq. per year, equivalent to ca. $25 \%$ of the global terrestrial and ocean carbon sink (Borges et al., 2015). Nitrous oxide emissions in SSA contribute between 6 and $19 \%$ of the global total, and changes in soil $\mathrm{N}_{2} \mathrm{O}$ fluxes in SSA drive large interannual variations in tropical and subtropical $\mathrm{N}_{2} \mathrm{O}$ sources (Thompson et al., 2014; Hickman et al., 2011). Use of synthetic fertilizers such as urea has increased in the last four decades, as has the number of livestock (and their manure and urine products) in Africa (Bouwman et al., 2009, 2013). The increasing trend in $\mathrm{N}$ application rates is expected to cause a 2-fold increase in agricultural $\mathrm{N}_{2} \mathrm{O}$ emissions in the continent by 2050 (from 2000; Hickman et al., 2011). In the case of $\mathrm{CH}_{4}$ emissions, there are important differences between ecosystems. Tropical humid forest, wetlands, rice paddy fields, and termite mounds are likely sources of $\mathrm{CH}_{4}$, while seasonally dry forests and savannahs are typically $\mathrm{CH}_{4}$ sinks (Valentini et al., 2014).

Interpretation of GHG emissions from soils and terrestrial water bodies is complex because of the multiple, sometimes competing, biological, chemical, and physical processes affecting fluxes. Spatial and temporal variability in GHG fluxes is also high and challenging to capture with direct measurement. This in turn makes reliable annual GHG flux estimates

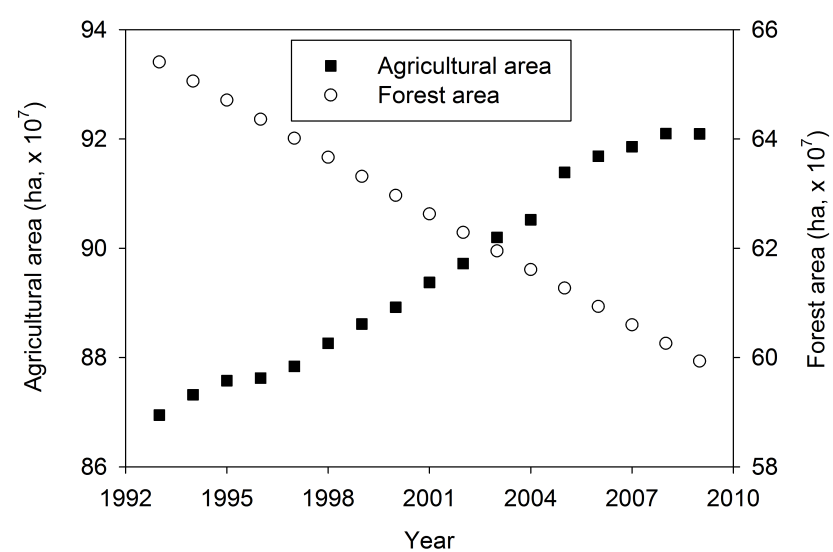

Figure 1. Change in areas of agricultural land and forest in Africa. Data source: FAOSTAT, http://faostat.fao.org/site/377/ default.aspx\#ancor.

from different soils, land uses, and regions quite rare in SSA. Net soil $\mathrm{CO}_{2}$ flux is largely a product of autotrophic respiration derived from plant roots and heterotrophic respiration of soil organic matter (Raich and Schlesinger, 1992). Soil $\mathrm{CO}_{2}$ flux provides an integrated result of biological $\mathrm{CO}_{2}$ production throughout the soil column, changes in soil $\mathrm{CO}_{2}$ diffusivity in the soil profile, and in some areas geological processes (Raich and Schlesinger, 1992). Net $\mathrm{CH}_{4}$ flux flux is the result of the balance between methanogenesis (microbial production under anaerobic conditions) and methanotrophy (microbial consumption) (Dutaur and Verchot, 2007). Methanogenesis occurs via the anaerobic degradation of organic matter by methanogenic archaea within the archaeal phylum Euryarchaeota (Thauer, 1988). Methanotrophy occurs by methanotrophs metabolizing $\mathrm{CH}_{4}$ as their source of carbon and energy (Hanson and Hanson, 1996). Soil $\mathrm{N}_{2} \mathrm{O}$ in produced through three main processes such as nitrification (Kowalchuk and Stephen, 2001), denitrification (Knowles, 1982), and nitrifier denitrification (Wrage et al., 2001. Identifying controlling factors and their effects on all GHGs is therefore complex and challenging but a pre-requisite to enhancing our understanding of efflux mechanisms and accurate quantification of GHG emissions. Environmental factors such as soil properties (e.g., soil type, carbon, and nutrients; Pelster et al., 2012), climate characteristics (e.g., temperature, rainfall, drought; Dijkstra et al., 2012), and vegetation type (e.g., crop or forest types; Masaka et al., 2014) also affect GHG fluxes. Management practices can also play important roles in controlling GHG fluxes. The controlling management practices include land-use change (Kim and Kirschbaum, 2015), logging (Yashiro et al., 2008), changing water discharge (Wang et al., 2013), soil compaction (Ball et al., 1999), tillage (Sheehy et al., 2013), removal of crop residues (Jin et al., 2014), and $\mathrm{N}$ input (whether organic or inorganic; Hickman et al., 2015). 
Our current understanding of GHG emissions in SSA is particularly limited when compared to the potential the continent has as both a GHG sink and a source. This lack of data on GHG emissions from African natural and agricultural lands and the lack of a comprehensive analysis of existing data (i.e., type of emission drivers: natural factors or anthropic ones) hinder the progress of our understanding of GHG emissions on the continent (Hickman et al., 2014; Valentini et al., 2014; Ciais et al., 2011; Bombelli et al., 2009). In order to identify mitigation measures and other climate-smart interventions for the region, it is important to quantify baseline GHG emissions, as well as understand the impacts of different land-use management strategies on GHG emissions (e.g., Palm et al., 2010). In this study our objectives are to synthesize currently available data on GHG emissions in natural ecosystems and agricultural lands in SSA, create an inventory of information from studies on emissions, and select priority topics for future GHG emission studies in natural ecosystems and agricultural lands in SSA.

\section{Methodology}

\subsection{Data collection and analyses}

Data were acquired by searching existing peer-reviewed literature using the names of the sub-Saharan countries and the GHGs (i.e., $\mathrm{CO}_{2}, \mathrm{CH}_{4}, \mathrm{~N}_{2} \mathrm{O}$ ) as search terms (using Web of Science and Google Scholar; 1960-2015). These criteria yielded 310 peer-reviewed papers. To produce the quantitative summary of GHG emissions, we selected studies that reported in situ annual GHG emissions or those that provided enough information to estimate annual GHG emissions through unit conversion and/or extrapolation of given data. Data from 75 studies, conducted in 22 countries $(n=244)$ in SSA, were used and were further categorized as GHG emission in natural ecosystems $(n=117$; Supplement Table S1) and agricultural lands ( $n=127$; Table S2; Fig. 2). The category of GHG emissions in natural ecosystems were further divided into emissions from natural terrestrial systems (forest/plantation/woodland $(n=55)$, savannah/grassland $(n=31)$, termite mounds $(n=5)$, and salt pans $(n=1))$ and aquatic systems (streams/rivers $(n=14)$, wetlands/floodplains/lagoons/reservoirs/lakes $(n=11))(\mathrm{Ta}-$ ble 1). Greenhouse gas emissions in agricultural lands were subdivided into emissions from cropland $(n=105)$, rice paddies $(n=1)$, vegetable gardens $(n=5)$, and agroforestry $(n=16$; Table 1). Across all categories there were 174 $\mathrm{CO}_{2}, 201 \mathrm{CH}_{4}$, and $184 \mathrm{~N}_{2} \mathrm{O}$ emissions measurements. To allow comparison between different $\mathrm{GHG}$ emissions $\mathrm{CH}_{4}$ and $\mathrm{N}_{2} \mathrm{O}$ emissions were converted to $\mathrm{CO}_{2}$ eq. assuming a 100-year global warming potential and values of 34 and $298 \mathrm{~kg} \mathrm{CO}_{2}$ eq. for $\mathrm{CH}_{4}$ and $\mathrm{N}_{2} \mathrm{O}$, respectively (IPCC, 2013). Where $\mathrm{N}_{2} \mathrm{O}$ emission studies included experimental data from control plots with no $\mathrm{N}$ fertilizer additions (i.e., for background $\mathrm{N}_{2} \mathrm{O}$ emissions), and from plots with different levels of applied $\mathrm{N}$, a $\mathrm{N}_{2} \mathrm{O}$ emission factor (EF) was calculated following the IPCC (2006) Tier I methodology as follows:

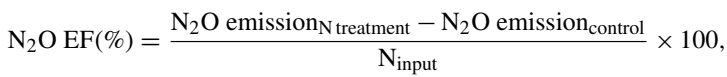

where $\mathrm{N}_{2} \mathrm{O}$ EF $(\%)$ is $\mathrm{N}_{2} \mathrm{O}$ emission factor, $\mathrm{N}_{2} \mathrm{O}$ emission $_{\mathrm{N}}$ treatment is $\mathrm{N}_{2} \mathrm{O}$ emission in $\mathrm{N}$ input, $\mathrm{N}_{2} \mathrm{O}$ emission $_{\text {control }}$ is control treatments with no $\mathrm{N}$ fertilizer additions, and $\mathrm{N}_{\text {input }}$ is the amount of added $\mathrm{N}$.

It should be noted that our data compilation includes a wide variety of studies that were conducted under diverse biophysical conditions using a range of methodologies for quantifying GHG emissions (e.g., different sampling protocols, chamber design, and emission rate calculations), soil properties, and climatic factors. Therefore, the overall figures on GHG emissions shown are based on results achieved by different measurement techniques with inherent and contrasting sources of error. To assess data quality of the cited studies we used the criteria (ranked from "very poor" to "very good") suggested by Rochette and Eriksen-Hamel (2008). These were originally intended for chamber $\mathrm{N}_{2} \mathrm{O}$ measurements but are equally applicable to field-based $\mathrm{CO}_{2}$ and $\mathrm{CH}_{4}$ chamber measurements. We went through the methods of the papers used in the study (only those for terrestrial emissions, since these criteria are not applicable for aquatic systems) where there was sufficient detail in the methods section. We categorized the studies as three different groups: the methods are (1) poor to very poor, (2) marginal and (3) good. Studies that were ranked "poor" on 3 or more criteria or "very poor" on 2 or more criteria were categorized as such because the methods were poor to very poor. In addition, we took into account the importance of sampling frequency (Barton et al., 2015) and sampling periods. Studies estimating annual GHG emissions with a sampling frequency lower than biweekly (i.e., less than two times per month) and sampling periods of less than 6 months (i.e., covering both rainy and dry seasons) were also categorized as poor to very poor. Studies that were ranked as "poor" on two criteria, or "very poor" on one criterion, or with insufficient details on the methods were ranked as marginal. The good studies were those with only one "poor" ranking, sufficient detail, and a sampling frequency of every 2 weeks or more frequent.

\subsection{Statistical analyses}

To determine the relationship between annual soil $\mathrm{CO}_{2}$ emissions and edaphic and climatic factors (e.g., soil pH, soil bulk density, soil organic carbon (SOC), total N, and annual average air temperature and rainfall) in SSA natural terrestrial systems and agricultural lands, we used a Pearson correlation analysis. The compiled datasets were used to examine the best model fit selection for $\mathrm{N}_{2} \mathrm{O}$ emissions and yieldscaled $\mathrm{N}_{2} \mathrm{O}$ emissions as a function of the respective $\mathrm{N}$ input levels. Different data fitting models (linear, nonlinear, 
Table 1. Summary of greenhouse gas carbon dioxide $\left(\mathrm{CO}_{2}\right)$, methane $\left(\mathrm{CH}_{4}\right)$, nitrous oxide $\left(\mathrm{N}_{2} \mathrm{O}\right)$, emissions and $\mathrm{CO}_{2}$ equivalents $\left(\mathrm{CO}_{2}\right.$ eq. $)$ in natural ecosystems and agricultural lands in sub-Saharan African countries. Mean \pm standard error (number of data) are shown.

\begin{tabular}{|c|c|c|c|c|c|c|c|}
\hline & & $\mathrm{CO}_{2}$ emission & $\mathrm{CH}_{4}$ emission & $\mathrm{N}_{2} \mathrm{O}$ emission & $\begin{array}{l}\mathrm{N}_{2} \mathrm{O} \text { emission } \\
\text { factor }\end{array}$ & $\begin{array}{l}\mathrm{CO}_{2} \text { eq. } \\
\text { emission }\end{array}$ & $\begin{array}{c}\text { Total } \mathrm{CO}_{2} \text { eq. } \\
\text { emission }\end{array}$ \\
\hline Type & Area (Mha) & $\mathrm{MgCO}_{2} \mathrm{ha}^{-1} \mathrm{yr}^{-1}$ & $\mathrm{kgCH}_{4} \mathrm{ha}^{-1} \mathrm{yr}^{-1}$ & $\mathrm{~kg} \mathrm{~N}_{2} \mathrm{Oha}^{-1} \mathrm{yr}^{-1}$ & $\%$ & $\mathrm{MgCO}_{2}$ eq. $\mathrm{ha}^{-1} \mathrm{yr}^{-1}$ & $\times 10^{\mathrm{i}} \mathrm{Mg} \mathrm{CO}_{2}$ eq. $\mathrm{yr}^{-1}$ \\
\hline Forest/plantation/woodland & $740.6^{\mathrm{a}}$ & $32.0 \pm 5.0(34)$ & $-1.5 \pm 0.6(15)$ & $4.2 \pm 1.5(10)$ & d & $34.0 \pm 5.7$ & $25.2 \pm 4.2$ \\
\hline Savannah/grassland & $638.9^{\mathrm{a}}$ & $15.5 \pm 3.8(11)$ & $0.5 \pm 0.4(18)$ & $0.6 \pm 0.1(6)$ & d & $15.8 \pm 3.8$ & $10.1 \pm 2.4$ \\
\hline Stream/river & $28.2^{\mathrm{a}}$ & $78.1 \pm 13.2(27)$ & $436.3 \pm 133.8(24)$ & $1.6 \pm 0.3(17)$ & $\mathrm{d}$ & $93.4 \pm 17.9$ & $2.8 \pm 1.0$ \\
\hline Wetlands/floodplains/lagoons/reservoir & $43.8^{\mathrm{a}}$ & $96.6 \pm 31.0(7)$ & $950.4 \pm 350.4(5)$ & $2.0 \pm 1.5(2)$ & $\mathrm{d}$ & $121.3 \pm 39.7$ & $5.3 \pm 1.7$ \\
\hline Termite mounds & $0.97^{\mathrm{b}}$ & $11.6 \pm 6.2(3)$ & $2.3 \pm 1.1(3)$ & $0.01(1)$ & d & $11.7 \pm 6.3$ & $0.01 \pm 0.01$ \\
\hline Salt pan & d & $0.7(1)$ & d & d & d & $\mathrm{d}$ & d \\
\hline Total natural ecosystems ${ }^{\mathrm{h}}$ & 1452.5 & $27.6 \pm 2.9^{\mathrm{e}}$ & $43.0 \pm 5.8^{\mathrm{e}}$ & $2.5 \pm 0.4^{\mathrm{e}}$ & d & $29.9 \pm 22.5^{\mathrm{e}}$ & $43.4 \pm 9.3(76.3 \%)^{\mathrm{g}}$ \\
\hline Cropland & $468.7^{\mathrm{a}}$ & $23.4 \pm 5.1(45)$ & $19.3 \pm 4.2(26)$ & $4.0 \pm 1.5(83)$ & $0.5 \pm 0.2(24)$ & $26.1 \pm 6.0$ & $12.2 \pm 2.8$ \\
\hline Rice field & $10.5^{\mathrm{c}}$ & $6.5(1)$ & $30.5(1)$ & $0.19(1)$ & d & 7.3 & $1.3 \pm 0.6$ \\
\hline Vegetable gardens & d & $96.4 \pm 10.2(5)$ & d & $120.1 \pm 26.1(5)$ & $3.5 \pm 0.5(2)$ & d & d \\
\hline Agroforestry & $190^{\mathrm{f}}$ & $38.6(1)$ & d & $4.7 \pm 2.2(15)$ & d & d & d \\
\hline Total agricultural lands ${ }^{\mathrm{i}}$ & 479.2 & $23.0 \pm 8.5^{\mathrm{e}}$ & $19.5 \pm 5.6^{\mathrm{e}}$ & $4.5 \pm 2.2^{\mathrm{e}}$ & d & $25.6 \pm 12.4^{\mathrm{e}}$ & $13.5 \pm 3.4(23.7 \%)^{\mathrm{g}}$ \\
\hline $\begin{array}{l}\text { Total natural ecosystems } \\
\text { and agricultural lands } \mathrm{j}^{\mathrm{j}}\end{array}$ & 1931.7 & & & & & & $56.9 \pm 12.7$ \\
\hline
\end{tabular}
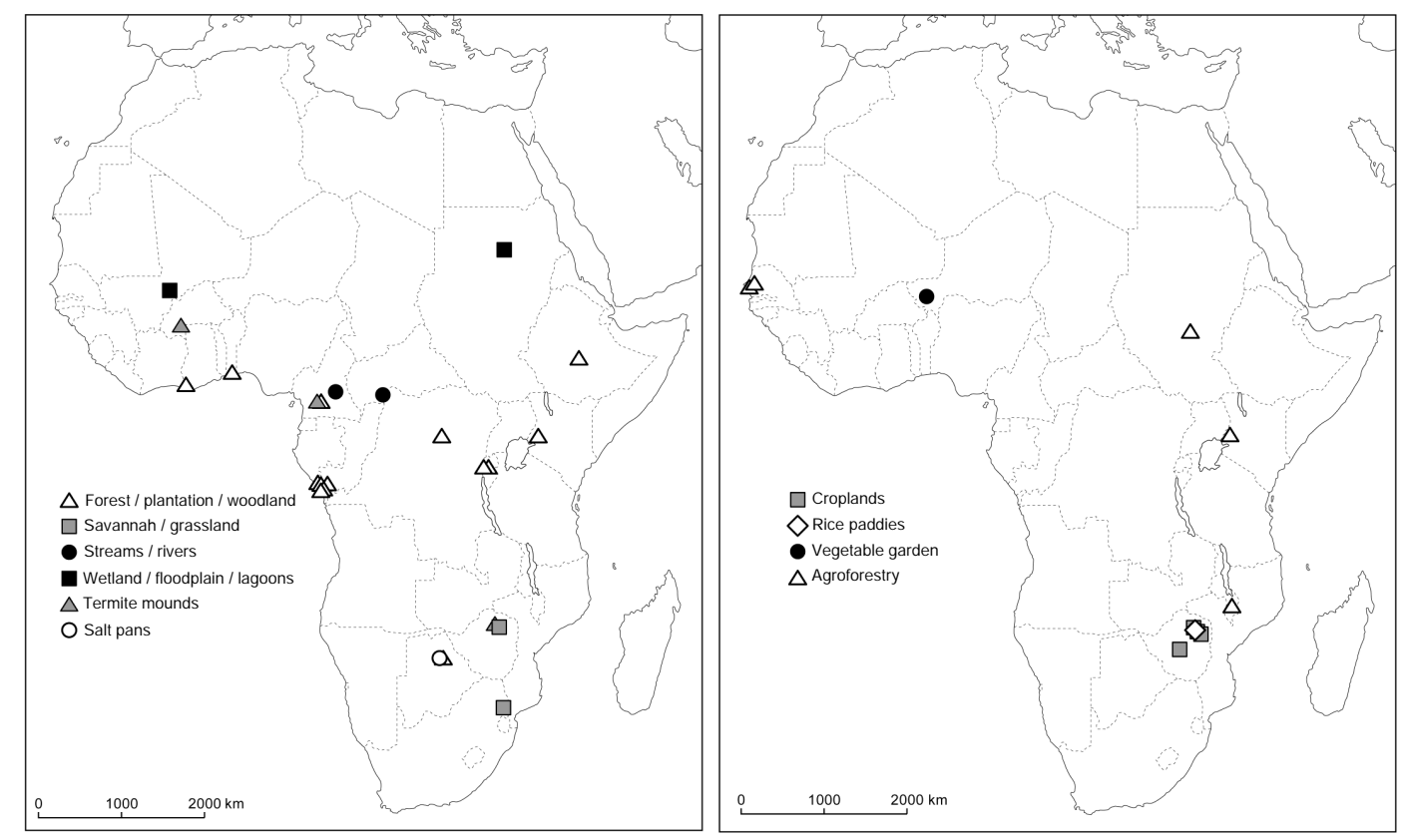

Figure 2. Maps showing study sites of $\mathrm{CO}_{2}, \mathrm{CH}_{4}$, and $\mathrm{N}_{2} \mathrm{O}$ fluxes in natural ecosystems (left) and agricultural lands (right) in sub-Saharan Africa.

natural log, logarithm, and sigmoidal) were tested for each dataset. The regression models were checked for violation of assumptions of normal distribution (Shapiro-Wilk test), homoscedasticity (Breusch-Pagan test), and constant variance (Durbin-Watson statistic; Motulsky and Christopoulos, 2004). Separate $t$ tests were used to assess significance of regression coefficients and intercepts in the fitted parametric models. Adjusted coefficients of determination (adjusted $R^{2}$ ) of fitted parametric models were used as criteria for model selection: the model with the highest adjusted $R^{2}$ was selected. Statistical significance was considered at the critical level of $5 \%$. Statistical analyses were conducted using $\mathrm{SAS}^{\circledR}$ version 9.2 (SAS Institute, Cary, NC, USA) and SigmaPlot ${ }^{\circledR}$ version 11.0 (Systat Software Inc., San Jose, CA, USA).

\section{Results and discussion}

\subsection{Summary of greenhouse gas emissions}

\subsection{1 $\mathrm{CO}_{2}$ emissions}

Carbon dioxide emissions ranged from 3.3 to 130.9 $\mathrm{MgCO}_{2} \mathrm{ha}^{-1} \mathrm{yr}^{-1}$ in natural terrestrial systems and from -11.9 to $232.0 \mathrm{MgCO}_{2} \mathrm{ha}^{-1} \mathrm{yr}^{-1}$ 
in aquatic systems. The area-weighted average was $27.6 \pm 17.2 \mathrm{MgCO}_{2} \mathrm{ha}^{-1} \mathrm{yr}^{-1}$ (Tables 1 and S1). Aquatic systems such as water bodies or water submerged lands were the largest source of $\mathrm{CO}_{2}$, followed by forest, savannah, termite mounds, and salt pans (Table 1). Soil $\mathrm{CO}_{2}$ emissions in agricultural lands were similar to emissions from natural lands and ranged from 6.5 to $141.2 \mathrm{MgCO}_{2} \mathrm{ha}^{-1} \mathrm{yr}^{-1}$ with an area-weighted average of $23.0 \pm 8.5 \mathrm{MgCO}_{2} \mathrm{ha}^{-1} \mathrm{yr}^{-1}$ (Tables 1 and S2). Vegetable gardens were the largest sources of $\mathrm{CO}_{2}$ emission largely due to the excessive $\mathrm{C}$ inputs. However, this conclusion was based on two studies that used photoacoustic spectroscopy, which has been found have mixed results due to cross sensitivities between the various GHG and water vapor (Rosenstock et al., 2013; Iqbal et al., 2013), suggesting that vegetable gardens require further study. The next largest sources of emissions were agroforestry, cropland, and then rice production systems (Tables 1 and S2).

Observed annual soil $\mathrm{CO}_{2}$ emissions in African natural terrestrial systems and agricultural lands showed significant correlations with annual mean air temperature $(r=-0.322$, $P=0.01)$, annual rainfall $(r=0.518, P<0.001)$, SOC $(r=0.626, P<0.001)$, and soil total N content $(r=0.849$, $P<0.001$; Table 2). The negative relationship between annual soil $\mathrm{CO}_{2}$ emissions and annual mean air temperature was unexpected since positive correlations between soil $\mathrm{CO}_{2}$ flux and temperature are well established (e.g., BondLamberty and Thomson, 2010). We speculate that the generally high temperatures, and poor quality, of many African soils mean that air temperature increases frequently result in vegetation stress and/or soil aridity, hindering root and soil microbial activities (root and microbial respiration) and subsequent soil $\mathrm{CO}_{2}$ flux (e.g., Thomas et al., 2011). This would account for the negative relationship observed between annual mean air temperature and annual soil $\mathrm{CO}_{2}$ emissions, but this remains a largely untested hypothesis that deserves further exploration.

Many of these estimates are based on short-term, infrequent, or poor-quality sampling (Table S1), suggesting that the uncertainties are likely much greater than the provided standard error. This is not meant as a critique of these studies, as many of them were specifically designed to answer specific research questions about the effects of various factors on emission rates rather than determining the cumulative annual emissions. However, given the lack of other data, these still provide the "best guess" for cumulative emissions.

\subsection{2 $\mathrm{CH}_{4}$ emissions}

Forest/plantation/woodland were sinks of $\mathrm{CH}_{4}$ $\left(-1.5 \pm 0.6 \mathrm{~kg} \mathrm{CH}_{4} \mathrm{ha}^{-1} \mathrm{yr}^{-1}\right)$ and savannah/grassland, croplands, termite mounds, and rice fields were low to moderate $\mathrm{CH}_{4}$ sources $\left(0.5-30.5 \mathrm{~kg} \mathrm{CH}_{4} \mathrm{ha}^{-1} \mathrm{yr}^{-1}\right)$. Stream/river and wetland/floodplain/lagoon/reservoir were high $\mathrm{CH}_{4}$ sources (766.0-950.4 $\mathrm{kg} \mathrm{CH}_{4} \mathrm{ha}^{-1} \mathrm{yr}^{-1}$; Tables 1


Figure 3. Relationship between nitrogen $(\mathrm{N})$ input and nitrous oxide $\left(\mathrm{N}_{2} \mathrm{O}\right)$ emissions observed in Africa. $\mathrm{N}$ input ranged from 0 to 300 (a), 300 to 4000 (b), and 0 to $4000 \mathrm{~kg} \mathrm{Nha}^{-1} \mathrm{yr}^{-1}$ (c). The dashed lines indicate $95 \%$ confidence intervals. "Control" indicates no fertilizer application, Organic fertilizer is manure; "Inorganic fertilizer" includes NPK, ammonium nitrate, and urea fertilizers; and "Mixture" indicates mixed application of organic and inorganic fertilizers.

and S1). The area-weighted averages of $\mathrm{CH}_{4}$ emissions from natural and agricultural lands were $43.0 \pm 5.8$ and $19.5 \pm 5.6 \mathrm{~kg} \mathrm{CH}_{4} \mathrm{ha}^{-1} \mathrm{yr}^{-1}$, respectively. As with studies on $\mathrm{CO}_{2}$ emissions, many of these studies used only infrequent or poor sampling methodologies (Table S1), and there is a high degree of uncertainty surrounding the estimates.

\subsection{3 $\quad \mathrm{N}_{2} \mathrm{O}$ emissions and emission factor (EF)}

Nitrous oxide emissions in natural ecosystems ranged from -0.1 to $13.7 \mathrm{~kg} \mathrm{~N}_{2} \mathrm{O} \mathrm{ha}^{-1} \mathrm{yr}^{-1}$ and the area-weighted aver- 
Table 2. Correlation between annual soil $\mathrm{CO}_{2}$ emissions $\left(\mathrm{MgCO}_{2} \mathrm{ha}^{-1} \mathrm{yr}^{-1}\right)$ and environmental factors in African natural terrestrial systems.

\begin{tabular}{lcccc}
\hline & $\begin{array}{c}\text { Annual mean air } \\
\text { temperature }\left({ }^{\circ} \mathrm{C}\right)\end{array}$ & $\begin{array}{c}\text { Annual } \\
\text { rainfall }(\mathrm{mm})\end{array}$ & $\begin{array}{c}\text { Soil organic } \\
\text { carbon }(\%)\end{array}$ & $\begin{array}{c}\text { Soil total } \\
\text { nitrogen }(\%)\end{array}$ \\
\hline Correlation coefficient & -0.322 & 0.518 & 0.626 & 0.849 \\
$P$ value & 0.01 & $<0.001$ & $<0.001$ & $<0.001$ \\
Number of samples & 60 & 61 & 31 & 26 \\
\hline
\end{tabular}

age was $2.5 \pm 0.8 \mathrm{~kg} \mathrm{~N}_{2} \mathrm{O} \mathrm{ha}^{-1} \mathrm{yr}^{-1}$ (Tables 1 and S1). Our study reveals that forest, plantation, and woodland were the largest source of $\mathrm{N}_{2} \mathrm{O}$, followed by rivers and wetlands, savannah, and termite mounds in natural ecosystems (Table 1). Soil $\mathrm{N}_{2} \mathrm{O}$ emissions in agricultural lands ranged from 0.051 to $177.6 \mathrm{~kg} \mathrm{~N}_{2} \mathrm{O} \mathrm{ha}^{-1} \mathrm{yr}^{-1}$ and the area-weighted average was $4.5 \pm 2.2 \mathrm{~kg} \mathrm{~N}_{2} \mathrm{Oha}^{-1} \mathrm{yr}^{-1}$ (Tables 1 and S2). The largest $\mathrm{N}_{2} \mathrm{O}$ source in agricultural lands was vegetable gardens, followed by agroforestry, cropland, and rice fields (Table 1). The $\mathrm{N}_{2} \mathrm{O}$ EF was $0.5 \pm 0.2$ and $3.5 \pm 0.5 \%$ for cropland and vegetable gardens, respectively (Tables 1 and $\mathrm{S} 1$ ). The $\mathrm{N}_{2} \mathrm{O}$ EF of cropland is lower and the $\mathrm{N}_{2} \mathrm{O}$ EF of vegetable gardens is higher than IPCC default $\mathrm{N}_{2} \mathrm{O}$ EF (1\%; IPCC, 2006). The number of studies on $\mathrm{N}_{2} \mathrm{O}$ emissions in SSA is, however, particularly low $(n=14)$, with some questions regarding the quality of the methods (Table S1) in some of these studies, and there are significant regional gaps leading to large uncertainties in the conclusions that can be currently drawn.

$\mathrm{N}_{2} \mathrm{O}$ emissions were significantly affected by $\mathrm{N}$ input levels (Fig. 3). $\mathrm{N}_{2} \mathrm{O}$ emissions increase slowly up to $150 \mathrm{~kg} \mathrm{Nha}^{-1} \mathrm{yr}^{-1}$, after which emissions increase exponentially up to $300 \mathrm{~kg} \mathrm{Nha}^{-1} \mathrm{yr}^{-1}$ (Fig. 3a). Consistent with earlier work by Van Groenigen et al. (2010), N inputs of over $300 \mathrm{~kg} \mathrm{~N} \mathrm{ha}^{-1} \mathrm{yr}^{-1}$ resulted in an exponential increase in emission (Fig. 3b), slowing to a steady state with $\mathrm{N}$ inputs of $3000 \mathrm{~kg} \mathrm{Nha}^{-1} \mathrm{yr}^{-1}$. Overall, the relationship between $\mathrm{N}$ input and $\mathrm{N}_{2} \mathrm{O}$ emissions shows a sigmoidal pattern (Fig. 3c). The observed relationship is consistent with the proposed hypothetical conceptualization of $\mathrm{N}_{2} \mathrm{O}$ emission by Kim et al. (2013), showing a sigmoidal response of $\mathrm{N}_{2} \mathrm{O}$ emissions to $\mathrm{N}$ input increases. The results suggest that $\mathrm{N}$ inputs over $150 \mathrm{~kg} \mathrm{Nha}^{-1} \mathrm{yr}^{-1}$ may cause an abnormal increase in $\mathrm{N}_{2} \mathrm{O}$ emissions in SSA. The relationship between $\mathrm{N}$ input and $\mathrm{N}_{2} \mathrm{O}$ emissions shows that the lowest yield-scaled $\mathrm{N}_{2} \mathrm{O}$ emissions were reported for $\mathrm{N}$ application rates ranging from 100 to $150 \mathrm{~kg} \mathrm{Nha}^{-1}$ (Fig. 4). The results are in line with the global meta-analysis of Philiber et al. (2012), who showed that from an $\mathrm{N}$ application rate $\sim 150 \mathrm{~kg} \mathrm{Nha}^{-1}$ the increase in $\mathrm{N}_{2} \mathrm{O}$ emissions is not linear but exponential.

\subsection{4 $\mathrm{CO}_{2}$ eq. emission}

Carbon dioxide equivalent emission (including $\mathrm{CO}_{2}, \mathrm{CH}_{4}$, and $\mathrm{N}_{2} \mathrm{O}$ ) in natural ecosystems ranged from 11.7 to
121.3 $\mathrm{MgCO}_{2}$ eq. $\mathrm{ha}^{-1} \mathrm{yr}^{-1}$ and the area-weighted average of $\mathrm{CO}_{2}$ eq. emissions (excluding salt pans) was $29.9 \pm 22.5 \mathrm{MgCO}_{2}$ eq. $\mathrm{ha}^{-1} \mathrm{yr}^{-1}$ (Table 1). Water bodies or water submerged lands such as rivers and wetlands were the largest source of $\mathrm{CO}_{2}$ eq. emissions, followed by forest/plantation/woodland, savannah/grassland, and termite mounds (Table 1). Carbon dioxide equivalent emissions in agricultural lands ranged from 7.3 to $26.1 \mathrm{MgCO}_{2}$ eq. $\mathrm{ha}^{-1} \mathrm{yr}^{-1}$ and had an area-weighted average of $\mathrm{CO}_{2}$ eq. emissions (excluding vegetable gardens and agroforestry due to lack of data) of $25.6 \pm 12.4 \mathrm{Mg} \mathrm{CO}_{2}$ eq. ha $^{-1} \mathrm{yr}^{-1}$ (Table 1).

Total $\mathrm{CO}_{2}$ eq. emissions in natural lands (excluding salt pans) were $43.4 \pm 9.3 \times 10^{9} \mathrm{MgCO}_{2}$ eq. $\mathrm{yr}^{-1}$, with forest/plantation/woodland the largest source, followed by savannah/grassland, stream/river, wetlands/floodplains/lagoons/reservoir, and termite mounds (Table 1). Total $\mathrm{CO}_{2}$ eq. emissions in agricultural lands (excluding vegetable gardens and agroforestry) were $13.5 \pm 3.4 \times 10^{9} \mathrm{Mg} \mathrm{CO}_{2}$ eq. $\mathrm{yr}^{-1}$, with cropland the largest source, followed by rice fields (Table 1). Overall, total $\mathrm{CO}_{2}$ eq. emissions in natural ecosystems and agricultural lands were $56.9 \pm 12.7 \times 10^{9} \mathrm{Mg} \mathrm{CO}_{2}$ eq. $\mathrm{yr}^{-1}$ with natural ecosystems and agricultural lands contributing 76.3 and $23.7 \%$, respectively.

\subsubsection{Data quality assessment}

For the purposes of this study more than half of the 75 studies cited in the study were categorized as having poor to very poor methods, 19 studies were marginal, and 14 studies were good (Tables S1 and S2). The primary reasons the studies were ranked as poor to very poor were because sampling periods were too short for calculating annual emissions (i.e., less than or only one season of data), sampling frequency was too low (i.e., monthly or less), or a combination of poor methods with the sample collection, primarily insufficient samples per gas collecting chamber and very long chamber deployment times. As mentioned earlier, many of these studies were undertaken to address a specific research question, not determine annual, cumulative emissions. Therefore, the degree of uncertainty around cumulative emissions is likely higher than what is indicated in Table 1. 

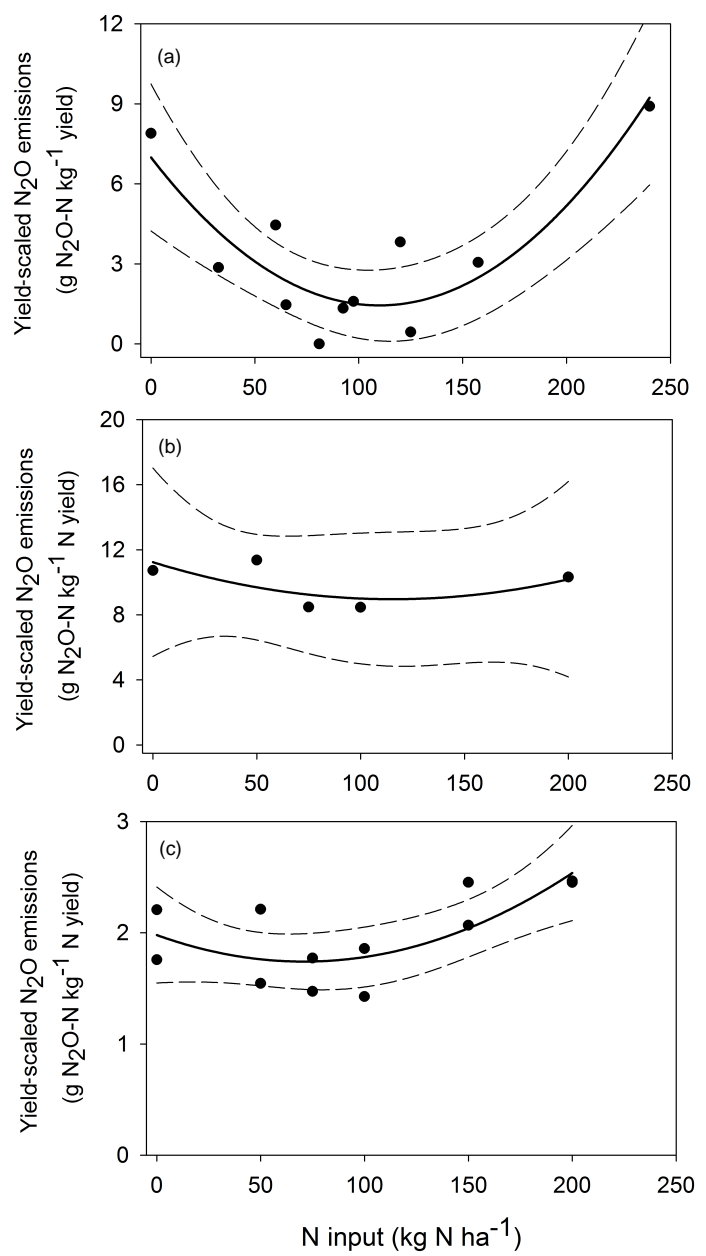

Figure 4. Relationship between nitrogen $(\mathrm{N})$ input and yield scaled nitrous oxide $\left(\mathrm{N}_{2} \mathrm{O}\right)$ emissions. Grain type: (a) rape (Brassica na$p u s)$ and (b, c) maize (Zea mays L.). Data sources: (a) from Nyamadzawo et al. (2014a), (b) from Hickman et al. (2014) and (c) from Hickman et al. (2015). The dashed lines indicate $95 \%$ confidence intervals. Note the different scales across panels.

\subsection{Sources and drivers of greenhouse gas emissions in Africa}

\subsubsection{Greenhouse gas emissions in natural ecosystems}

\section{Natural terrestrial systems}

A range of factors affect direct emissions of soil $\mathrm{CO}_{2}$ in SSA natural terrestrial systems such as natural forest, plantation, woodland, savannah, grassland, termite mounds, and salt pans. These factors can be grouped into (i) climatic, (ii) edaphic, (iii) vegetation, and (iv) human interventions via land management (Tables 3 and 4). Data on the effects of these factors on GHG emissions are variable, with some factors much less well understood than others. In almost all cases data are limited to a few studies, and there are areas where there has been no research. This lack of data hinders our ability to estimate the contribution of African landscapes to global GHG emissions.

Soil $\mathrm{CO}_{2}$ emissions were related to both soil moisture and temperature in forest systems (Table 3). For example, soil moisture explained about $50 \%$ of the seasonal variability in soil $\mathrm{CO}_{2}$ efflux in a Croton macrostachys, Podocarpus falcatus, and Prunus africana forest in Ethiopia (Yohannes et al., 2011), as well as much of the seasonal variation in soil $\mathrm{CO}_{2}$ efflux in a 3-year-old Eucalyptus plantation in the Republic of Congo (Epron et al., 2004). Thomas et al. (2011) found that the $\mathrm{Q}_{10}$ of soil $\mathrm{CO}_{2}$ efflux (a measure of the temperature sensitivity of efflux, where a $\mathrm{Q}_{10}$ of 2 represents a doubling of efflux given a $10^{\circ} \mathrm{C}$ increase in temperature) was dependent on soil moisture at sites across the Kalahari in Botswana, ranging from 1.1 in dry soils to 1.5 after a $2 \mathrm{~mm}$ rainfall event and 1.95 after a $50 \mathrm{~mm}$ event. Similarly, in a Zambian woodland, the main driving factor controlling $\mathrm{CO}_{2}$ emissions at a seasonal timescale was a combination of soil water content and temperature (Merbold et al., 2011).

Increased GHG emissions following rewetting of dry soil were observed in various regions in SSA (Table 3). Two broad mechanisms responsible for increased soil GHG flux following rewetting of dry soil have been hypothesized: (1) enhanced microbial metabolism by an increase in available substrate due to microbial death and/or destruction of soil aggregates (commonly known as the Birch effect; Birch, 1964), and (2) physical mechanisms influencing gas flux, including infiltration, reduced diffusivity, and gas displacement in the soil (e.g., Kim et al., 2012). Soil $\mathrm{CO}_{2}$ efflux increased immediately after rainfall in a subtropical palm woodland in northern Botswana; however, the increase was short-lived (Thomas et al., 2014). Large pulses of $\mathrm{CO}_{2}$ and $\mathrm{N}_{2} \mathrm{O}$, followed by a steady decline, were also observed after the first rainfall event of the wet season in a Kenyan rainforest (Werner et al., 2007). Soil $\mathrm{CO}_{2}$ efflux was strongly stimulated by addition of rainfall in a South African savannah (Fan et al., 2015; Zepp et al., 1996). In Zimbabwe, the release of $\mathrm{N}_{2} \mathrm{O}$ from dryland savannahs was shown to constitute an important pathway of release for $\mathrm{N}$, and emissions were strongly linked to patterns of rainfall (Rees et al., 2006). The results suggest that soil rewetting has a significant impact on GHG emissions in SSA.

Soil physical (e.g., bulk density, porosity, and soil texture) and chemical properties (e.g., pH, C, and N) also affect soil GHG emissions (e.g., Saggar et al., 2013; Smith, 2010; Snyder et al., 2009; Table 3). Soil $\mathrm{CO}_{2}$ efflux was positively related to total soil $\mathrm{C}$ content in undisturbed miombo woodland in Zambia, although not in an adjacent disturbed woodland (Merbold et al., 2011). In a Kenyan rainforest, $\mathrm{CO}_{2}$ emissions were negatively correlated with subsoil $\mathrm{C}$ and positively correlated with subsoil $\mathrm{N}$ concentrations, while $\mathrm{N}_{2} \mathrm{O}$ emissions were negatively correlated with clay content and topsoil C: N ratios (Werner et al., 2007). However, soil bulk density and $\mathrm{pH}$ were the most influential factors driving spatial variation of in situ $\mathrm{N}_{2} \mathrm{O}$ emissions in a tropical high- 
Table 3. Summary of environmental factors affecting greenhouse gas (GHG) emissions in land-use/ecosystem type. ○ indicates GHG affected by environmental factor named.

\begin{tabular}{|c|c|c|c|c|c|}
\hline \multirow[b]{2}{*}{ Land-use/ecosystem type } & \multirow[b]{2}{*}{ Environmental factors } & \multicolumn{3}{|c|}{ GHG } & \multirow[b]{2}{*}{ Location (data source) } \\
\hline & & $\mathrm{CO}_{2}$ & $\mathrm{~N}_{2} \mathrm{O}$ & $\mathrm{CH}_{4}$ & \\
\hline \multirow{10}{*}{$\begin{array}{l}\text { Forest/plantation/ } \\
\text { Woodland }\end{array}$} & Temperature & $\bullet$ & & & Zambia (Merbold et al., 2011) \\
\hline & Soil moisture & $\bullet$ & & & $\begin{array}{l}\text { Ethiopia (Yohannes et al., 2011), } \\
\text { Republic of Congo (Epron et al., 2004), } \\
\text { Botswana (Thomas et al., 2011), } \\
\text { Zambia (Merbold et al., 2011) }\end{array}$ \\
\hline & Rewetting of dry soil/rainfall & $\bullet$ & $\bullet$ & & Kenya (Werner et al., 2007) \\
\hline & Soil carbon & $\bullet$ & & & $\begin{array}{l}\text { Zambia (Merbold et al., 2011), } \\
\text { Kenya (Werner et al., 2007) }\end{array}$ \\
\hline & Soil nitrogen & $\bullet$ & & & Kenya (Werner et al., 2007) \\
\hline & Soil C : N & & $\bullet$ & & Kenya (Werner et al., 2007) \\
\hline & Soil clay & & $\bullet$ & & Kenya (Werner et al., 2007) \\
\hline & Soil bulk density & & $\bullet$ & & Rwanda (Gharahi Ghehi et al., 2014) \\
\hline & Soil pH & & $\bullet$ & & Rwanda (Gharahi Ghehi et al., 2014) \\
\hline & Vegetation type & $\bullet$ & & & $\begin{array}{l}\text { Republic of Congo (Epron et al., 2013; } \\
\text { Caquet et al., 2012; } \\
\text { Nouvellon et al., 2012) }\end{array}$ \\
\hline Savannah & Rewetting of dry soil/rainfall & $\bullet$ & $\bullet$ & & $\begin{array}{l}\text { South Africa (Fan et al., 2015; } \\
\text { Zepp et al., 1996), } \\
\text { Zimbabwe (Rees et al., 2006) }\end{array}$ \\
\hline \multirow[t]{2}{*}{ Salt pans } & Temperature & $\bullet$ & & & Botswana (Thomas et al., 2014) \\
\hline & Flooding & $\bullet$ & & & Botswana (Thomas et al., 2014) \\
\hline \multirow[t]{6}{*}{$\begin{array}{l}\text { Streams/rivers/ } \\
\text { wetlands/floodplains/ } \\
\text { reservoirs/lagoons/lakes }\end{array}$} & Type & $\bullet$ & & $\bullet$ & $\begin{array}{l}\text { Congo Basin (Mann et al., 2014), } \\
\text { Okavango Delta, Botswana } \\
\text { (Gondwe and Masamba, 2014), } \\
\text { Lake Kariba, Zambia/Zimbabwe } \\
\text { (DelSontro et al., 2011) }\end{array}$ \\
\hline & Location & $\bullet$ & $\bullet$ & $\bullet$ & $\begin{array}{l}\text { Zambezi River, Zambia/Mozambique } \\
\text { (Teodoru et al., 2015), } \\
\text { Zimbabwe (Nyamadzawo et al., 2014a) }\end{array}$ \\
\hline & Discharge & $\bullet$ & & $\bullet$ & $\begin{array}{l}\text { Congo River (Wang et al., 2013), } \\
\text { Ivory Coast (Koné et al., 2009), } \\
\text { Oubangui River, Central African Republic } \\
\text { (Bouillon et al., 2012), } \\
\text { Lake Kivu (Borges et al., 2011), } \\
\text { Zambezi River, Zambia/Mozambique } \\
\text { (Teodoru et al., 2015) }\end{array}$ \\
\hline & Precipitation & $\bullet$ & $\bullet$ & $\bullet$ & Uganda (Bateganya et al., 2015) \\
\hline & Water temperature & & & & $\begin{array}{l}\text { Okavango Delta, Botswana } \\
\text { (Gondwe and Masamba, 2014) }\end{array}$ \\
\hline & Dissolved inorganic carbon & $\bullet$ & & & $\begin{array}{l}\text { Lake Kivu, East Africa } \\
\text { (Borges et al., 2014) }\end{array}$ \\
\hline
\end{tabular}

land rainforest in Rwanda (Gharahi Ghehi et al., 2014). Similarly, a laboratory-based experiment using soils from 31 locations in a tropical mountain forest in Rwanda showed that $\mathrm{N}_{2} \mathrm{O}$ emissions were negatively correlated with soil $\mathrm{pH}$, and positively correlated with soil moisture, soil $\mathrm{C}$, and soil $\mathrm{N}$ (Gharahi Ghehi et al., 2012).
In many temperate systems, vegetation type also affects soil GHG emissions, likely because of differences in litter quality and production rate, amount of below-ground biomass, the structure of root systems, and plant-mediated effects on soil microclimate (e.g., Díaz-Pinés et al., 2014; Masaka et al., 2014; Kim et al., 2010). This is consistent with findings from African systems where annual soil $\mathrm{CO}_{2}$ 
Table 4. Summary of the effect of management practices on greenhouse gas (GHG) emissions. + indicates increasing, $\bullet$ indicates no change, and - indicates decreasing.

\begin{tabular}{|c|c|c|c|c|c|}
\hline \multirow[t]{2}{*}{ Land-use/ecosystem type } & \multirow[t]{2}{*}{ Management practices } & \multicolumn{3}{|c|}{ Impact on GHG } & \multirow[t]{2}{*}{ Country (data source) } \\
\hline & & $\mathrm{CO}_{2}$ & $\mathrm{~N}_{2} \mathrm{O}$ & $\mathrm{CH}_{4}$ & \\
\hline Forest/plantation/ & Burning & + & & & Ethiopia (Andersson et al., 2004) \\
\hline \multirow[t]{3}{*}{ Woodland } & Thinning & + & & & Ethiopia (Yohannes et al., 2013) \\
\hline & $\begin{array}{l}\text { Land-use change (cleaning } \\
\text { and conversion to croplands) }\end{array}$ & + & + & + & $\begin{array}{l}\text { Zimbabwe (Mapanda et al., 2012; } \\
\text { Mapanda et al., 2010) }\end{array}$ \\
\hline & Flooding & & & + & $\begin{array}{l}\text { Cameroon (Macdonald et al., 1998); } \\
\text { Republic of Congo (Tathy et al., 1992); } \\
\text { Mali (Delmas et al., 1991) }\end{array}$ \\
\hline \multirow[t]{2}{*}{ Savannah/grassland } & Burning & $\bullet$ & $\bullet$ & $\bullet$ & $\begin{array}{l}\text { Republic of Congo (Castaldi et al., 2010; } \\
\text { Delmas et al., 1991); } \\
\text { South Africa (Zepp et al., 1996) }\end{array}$ \\
\hline & $\begin{array}{l}\text { Land-use change (cleaning and } \\
\text { conversion to croplands) }\end{array}$ & + & & & $\begin{array}{l}{ }^{1} \text { Republic of Congo } \\
\text { (Nouvellon et al., 2012) }\end{array}$ \\
\hline \multirow[t]{15}{*}{ Croplands } & Increase in $\mathrm{N}$ fertilization rate & & + & & Kenya (Hickman et al., 2015) \\
\hline & Type of synthetic fertilizer & & $\bullet$ & & Madagascar (Rabenarivo et al., 2014) \\
\hline & Application of plant residues & & - & & $\begin{array}{l}\text { Tanzania (Sugihara et al., 2012); } \\
{ }^{2} \text { Madagascar (Rabenarivo et al., 2014) }\end{array}$ \\
\hline & & + & + & & $\begin{array}{l}\text { Kenya (Kimetu et al., 2007); } \\
{ }^{3} \text { Ghana (Frimpong et al., 2012) }\end{array}$ \\
\hline & Crop residues $+\mathrm{N}$ fertilizer & & + & & ${ }^{4}$ Zimbabwe (Nyamadzawo et al., 2014a, b) \\
\hline & & & - & & $\begin{array}{l}5 \text { Zimbabwe, Ghana, and Kenya } \\
\text { (Gentile et al., 2008) }\end{array}$ \\
\hline & $\begin{array}{l}\text { Combination of synthetic and organic } \\
\text { fertilizers and organic fertilizers }\end{array}$ & + & - & & ${ }^{6}$ Zimbabwe (Mapanda et al., 2011) \\
\hline & & & - & & ${ }^{7}$ Mali (Dick et al., 2008) \\
\hline & Crop type & $\bullet$ & & & ${ }^{8}$ Uganda (Koerber et al., 2009) \\
\hline & & & - & & ${ }^{9}$ Zimbabwe (Masaka et al., 2014) \\
\hline & $\begin{array}{l}\text { Introducing } \mathrm{N} \text { fixing } \\
\text { crops in rotations }\end{array}$ & & - & & Mali (Dick et al., 2008) \\
\hline & Direct seeding mulch-based & & $\bullet$ & & Madagascar (Chapuis-Lardy et al., 2009) \\
\hline & Hand ploughing after harvesting & & $\bullet$ & & Madagascar (Chapuis-Lardy et al., 2009) \\
\hline & Intensive grazing & + & & & Botswana (Thomas, 2012) \\
\hline & $\begin{array}{l}\text { Reduced tillage }+ \text { mulch, } \\
\text { leguminous crop/tree, or } \mathrm{N} \text { fertilizer }\end{array}$ & + & + & $+;-$ & Tanzania (Kimaro et al., 2016) \\
\hline \multirow[t]{2}{*}{ Vegetable gardens } & Plastic cover for ruminant manure & & - & & Niger (Predotova et al., 2010) \\
\hline & Incorporation of fallow residues & & + & & $\begin{array}{l}\text { Kenya (Baggs et al., 2006; } \\
\text { Millar and Baggs, 2004; } \\
\text { Millar et al., 2004) }\end{array}$ \\
\hline \multirow[t]{3}{*}{ Agroforestry } & Improving fallow with $\mathrm{N}$-fixing crops & & + & & Zimbabwe (Chikowo et al., 2004) \\
\hline & Cover crops & & + & & Kenya (Millar et al., 2004) \\
\hline & $\mathrm{N}$-fixing tree species & + & + & & $\begin{array}{l}\text { Malawi (Kim, 2012; } \\
\text { Makumba et al., 2007); } \\
\text { Senegal (Dick et al., 2006) }\end{array}$ \\
\hline
\end{tabular}

efflux also varied with vegetation types (Table 3). For example, annual soil $\mathrm{CO}_{2}$ emissions were significantly lower in $\mathrm{N}$-fixing acacia monocultures than in eucalypt monocultures and mixed-species stands in the Republic of Congo (Epron et al., 2013). The differences were attributed to leaf area index in another study from savannah grasslands in the Republic of Congo where they found $71 \%$ of seasonal soil $\mathrm{CO}_{2}$ efflux variability was explained by the quantity of photosynthetically active radiation absorbed by the grass canopy (Caquet et al., 2012). Also in the Republic of Congo, it was found 
that in forests, litterfall accounted for most of the age-related trends after the first year of growth, with litter decomposition producing $44 \%$ of soil $\mathrm{CO}_{2}$ flux in the oldest stand (Nouvellon et al., 2012), suggesting that the amount and quality of litter plays a major role in determining soil $\mathrm{CO}_{2}$ flux. However, the effect of vegetation type can also interact with soil physical-chemical properties. For example, in Benin, root respiration contributed to $30 \%$ of total soil $\mathrm{CO}_{2}$ efflux in oil palms when the soil was at field capacity and $80 \%$ when soil was dry (Lamade et al., 1996).

Forest management such as burning, which is a common practice in SSA, and thinning affects GHG emissions (Table 4). The IPCC Tier 1 methodology only calculates the amount of GHG emissions as a percentage of the carbon that is released through the burning; however, it may also increase forest soil GHG emissions once the fire has passed. For example, soil $\mathrm{CO}_{2}$ efflux immediately increased after burning of woodland in Ethiopia (Andersson et al., 2004); also, 5 days after burning, rainfall resulted in a 2 -fold increase in soil $\mathrm{CO}_{2}$ efflux from the burned plots compared to the unburned plots. In contrast, 12 days after burning soil $\mathrm{CO}_{2}$ efflux was $21 \%$ lower in the burned plots (Andersson et al., 2004). However, contrasting impacts of fire on soil GHG emission were observed in a savannah/grassland in the Republic of Congo, where fire did not change soil $\mathrm{CO}_{2}, \mathrm{CH}_{4}$, and $\mathrm{N}_{2} \mathrm{O}$ fluxes (Castaldi et al., 2010; Delmas et al., 1991). Similarly, in South Africa, soil $\mathrm{CH}_{4}$ efflux was not significantly affected by burning (Zepp et al., 1996). In contrast, annual fires decreased soil $\mathrm{CH}_{4}$ oxidation rates in a Ghanaian savannah (Prieme and Christensen, 1999). These case studies demonstrate that fire impacts are not always consistent and this is likely the result of different fire characteristics (e.g., intensity or frequency), soil type (e.g., Kulmala et al., 2014; Kim et al., 2011), and post-fire weather conditions. Thinning forest cover can also increase soil $\mathrm{CO}_{2}$ efflux. Yohannes et al. (2013) reported 24 and $14 \%$ increases in soil $\mathrm{CO}_{2}$ efflux in the first and second years following thinning of a 6-yearold Cupressus lusitanica plantation in Ethiopia.

There is a particular paucity of data on sources and sinks of $\mathrm{CH}_{4}$ in African natural terrestrial systems. In Cameroon, the largest $\mathrm{CH}_{4}$ oxidation rates were observed from relatively undisturbed near-primary forest sites $(-14.7$ to $\left.-15.2 \mathrm{ng} \mathrm{m}^{-2} \mathrm{~s}^{-1}\right)$ compared to disturbed forests $(-10.5$ to $0.6 \mathrm{ng} \mathrm{m}^{-2} \mathrm{~s}^{-1}$; Macdonald et al., 1998). Savannah and grassland were found to be both a sink and a source of $\mathrm{CH}_{4}$. In Mali, $\mathrm{CH}_{4}$ uptake was observed in dry sandy savannah (Delmas et al., 1991), while a savannah in Burkina Faso was found to be both a $\mathrm{CH}_{4}$ sink and source during the rainy season, although overall it was a net $\mathrm{CH}_{4}$ source (Brümmer et al., 2009). Termite mounds are known sources of $\mathrm{CH}_{4}$ and $\mathrm{CO}_{2}$ (Nyamadzawo et al., 2012; Brümmer et al., 2009). A study in a Burkina Faso savannah found that $\mathrm{CH}_{4}$ and $\mathrm{CO}_{2}$ released by termites (Cubitermes fungifaber) contributed 8.8 and $0.4 \%$ of total soil $\mathrm{CH}_{4}$ and $\mathrm{CO}_{2}$ emissions, respectively (Brümmer et al., 2009). In Cameroon, the mounds of soil- feeding termites (Thoracotermes macrothorax and Cubitermes fungifaber) were point sources of $\mathrm{CH}_{4}$, which at the landscape scale may exceed the general sink capacity of the soil (Macdonald et al., 1998). In Zimbabwe, it was found that Odontotermes transvaalensis termite mounds located in dambos (seasonal wetlands) were an important source of GHGs, and emissions varied with catena position for $\mathrm{CO}_{2}$ and $\mathrm{CH}_{4}$ (Nyamadzawo et al., 2012).

Compared to the other environments covered in this review there are very few studies from salt pans. Thomas et al. (2014), however, found soil $\mathrm{CO}_{2}$ efflux increased with temperature and also increased for a few hours after flooding of the surface of the Makgadikgadi salt pan in Botswana. Annual $\mathrm{CO}_{2}$ emissions in salt pan were estimated as $0.7 \mathrm{MgCO}_{2} \mathrm{ha}^{-1} \mathrm{yr}^{-1}$ (Thomas et al., 2014).

\section{Aquatic systems}

African aquatic systems such as streams, rivers, wetlands, floodplains, reservoirs, lagoons, and lakes can be significant sources of GHG (Tables 1 and S1). Differences in regional setting and hydrology mean that emissions are highly spatially and temporally variable, and when combined with the paucity of studies, it is challenging to identify clear control factors (Table 3).

Studies found SSA aquatic systems can be significant sources of GHG emissions. In Ivory Coast, three out of five lagoons were oversaturated in $\mathrm{CO}_{2}$ during all seasons and all were $\mathrm{CO}_{2}$ sources $\left(3.1-16.2 \mathrm{~g} \mathrm{CO}_{2} \mathrm{~m}^{-2} \mathrm{~d}^{-1}\right)$ due to net ecosystem heterotrophy and inputs of riverine $\mathrm{CO}_{2}$-rich waters (Koné et al., 2009). In the flooded forest zone of the Congo River basin (Republic of Congo) and the Niger River floodplain (Mali), high $\mathrm{CH}_{4}$ emissions $\left(5.16 \times 10^{20}\right.$ $6.35 \times 10^{22} \mathrm{~g} \mathrm{CH}_{4} \mathrm{~m}^{-2} \mathrm{~d}^{-1}$ ) were recorded on flooded soils (Tathy et al., 1992; Delmas et al., 1991). In the Nyong River (Cameroon), $\mathrm{CO}_{2}$ emissions (5.5 $\mathrm{kg} \mathrm{CO}_{2} \mathrm{~m}^{-2} \mathrm{yr}^{-1}$ ) were 4 times greater than the flux of dissolved inorganic carbon (Brunet et al., 2009). In the Zambezi River (Zambia), $38 \%$ of the total $\mathrm{C}$ in the river is emitted into the atmosphere, mostly as $\mathrm{CO}_{2}$ (98\%; Teodoru et al., 2015). The source of $\mathrm{CH}_{4}$ to the atmosphere from Lake Kivu corresponded to $\sim 60 \%$ of the terrestrial sink of atmospheric $\mathrm{CH}_{4}$ over the lake's catchment (Borges et al., 2011). A recent study of 10 river systems in SSA estimated water-air $\mathrm{CO}_{2}, \mathrm{CH}_{4}$, and $\mathrm{N}_{2} \mathrm{O}$ fluxes to be 8.2 to $66.9 \mathrm{~g} \mathrm{CO}_{2} \mathrm{~m}^{-2} \mathrm{~d}^{-1}, 0.008$ to $0.46 \mathrm{~g} \mathrm{CH}_{4} \mathrm{~m}^{-2} \mathrm{~d}^{-1}$, and 0.09 to $1.23 \mathrm{mg} \mathrm{N}_{2} \mathrm{O} \mathrm{m}^{-2} \mathrm{~d}^{-1}$, respectively (Borges et al., 2015). The authors suggested that lateral inputs of $\mathrm{CO}_{2}$ from soils, groundwater, and wetlands were the largest contributors of the $\mathrm{CO}_{2}$ emitted from the river systems (Borges et al., 2015).

The magnitude of GHG emissions from SSA aquatic systems varied with type and location (Table 3). Streams and rivers in savannah regions had higher $\mathrm{CO}_{2}$ emissions (46.8-56.4 $\left.\mathrm{g} \mathrm{CO}_{2} \mathrm{~m}^{-2} \mathrm{~d}^{-1}\right)$ than swamps (13.7$16.3 \mathrm{~g} \mathrm{CO}_{2} \mathrm{~m}^{-2} \mathrm{~d}^{-1}$ ) and tropical forest catchments 
(37.9-62.9 $\mathrm{g} \mathrm{CO}_{2} \mathrm{~m}^{-2} \mathrm{~d}^{-1}$ ) in the Congo Basin (Mann et al., 2014). The average $\mathrm{CH}_{4}$ flux in river channels $\left(0.75 \mathrm{~g} \mathrm{CH}_{4} \mathrm{~m}^{-2} \mathrm{~d}^{-1}\right)$ was higher than that in floodplains and lagoons $\left(0.41-0.49 \mathrm{~g} \mathrm{CH}_{4} \mathrm{~m}^{-2} \mathrm{~d}^{-1}\right)$ in the Okavango Delta (Botswana; Gondwe and Masamba, 2014). Methane emissions from river deltas were substantially higher $\left(\sim 103 \mathrm{mg} \mathrm{CH}_{4} \mathrm{~m}^{-2} \mathrm{~d}^{-1}\right)$ than those from non-river bays $\left(<100 \mathrm{mg} \mathrm{CH}_{4} \mathrm{~m}^{-2} \mathrm{~d}^{-1}\right)$ in Lake Kariba (Zambia/Zimbabwe). Methane fluxes were higher in river deltas $\left(\sim 103 \mathrm{mg} \mathrm{CH}_{4} \mathrm{~m}^{-2} \mathrm{~d}^{-1}\right)$ compared to non-river bays ( $\left.<100 \mathrm{mg} \mathrm{CH}_{4} \mathrm{~m}^{-2} \mathrm{~d}^{-1}\right)$ in Lake Kariba (Zambia/Zimbabwe; DelSontro et al., 2011). While $\mathrm{CO}_{2}$ and $\mathrm{CH}_{4}$ concentrations in the main channel were highest downstream of the floodplains, $\mathrm{N}_{2} \mathrm{O}$ concentrations were lowest downstream of the floodplains in the Zambezi River (Zambia and Mozambique; Teodoru et al., 2015). Greenhouse gas emissions from Dambos in Zimbabwe varied with catena position (Nyamadzawo et al., 2014a). Upland dambos were important sources of $\mathrm{N}_{2} \mathrm{O}$ and $\mathrm{CO}_{2}$, and a sink for $\mathrm{CH}_{4}$, while those in a mid-slope position were a major source of $\mathrm{CH}_{4}$ but a weak source of $\mathrm{CO}_{2}$ and $\mathrm{N}_{2} \mathrm{O}$, and those at the bottom were a weak source of all GHGs (Nyamadzawo et al., 2014a).

The concentration and flux of GHGs are strongly linked to hydrological characteristics such as discharge (Table 3), but clear patterns have not yet been identified. Surface $\mathrm{CO}_{2}$ flux was positively correlated with discharge in the Congo River (Wang et al., 2013), while in Ivory Coast, rivers were often oversaturated with $\mathrm{CO}_{2}$ and the seasonal variability in partial pressure of $\mathrm{CO}_{2}\left(p \mathrm{CO}_{2}\right)$ was due to dilution during the flooding period (Koné et al., 2009). Similarly, $\mathrm{CO}_{2}$ fluxes show a very pronounced seasonal pattern strongly linked to hydrological conditions in the Oubangui River in the Central African Republic (Bouillon et al., 2012). Although higher $\mathrm{CH}_{4}$ concentrations were found during low-discharge conditions, $\mathrm{N}_{2} \mathrm{O}$ concentrations were lowest during low-discharge conditions (Bouillon et al., 2012). In Lake Kivu, seasonal variations of $\mathrm{CH}_{4}$ in the main basin were driven by deepening of the mixolimnion and mixing of surface waters with deeper waters rich in $\mathrm{CH}_{4}$ (Borges et al., 2011). In the Zambezi River (Zambia and Mozambique), interannual variability was relatively large for $\mathrm{CO}_{2}$ and $\mathrm{CH}_{4}$ and significantly higher concentrations were measured during wet seasons (Teodoru et al., 2015). However, interannual variability in $\mathrm{N}_{2} \mathrm{O}$ was less pronounced and generally higher values were found during the dry season (Teodoru et al., 2015). In Kampala, Uganda, precipitation was a major driver for seasonal variation of $\mathrm{CO}_{2}, \mathrm{CH}_{4}$, and $\mathrm{N}_{2} \mathrm{O}$ fluxes in subsurface flow wetland buffer strips due to its potential influence on hydraulic saturation affecting oxygen fluctuation (Bateganya et al., 2015).

Studies found the concentration and flux of GHGs are also strongly linked to environment and water quality (Table 3) but clear patterns have not yet been identified. In the Okavango Delta (Botswana), $\mathrm{CH}_{4}$ emissions were highest during the warmer, summer rainy season and lowest during cooler winter season, suggesting the emissions were probably regulated by water temperature (Gondwe and Masamba, 2014). However, Borges et al. (2015) found no significant correlation between water temperature and $p \mathrm{CO}_{2}$ and dissolved $\mathrm{CH}_{4}$ and $\mathrm{N}_{2} \mathrm{O}$ in 11 SSA river systems, but there was a positive relationship between $p \mathrm{CO}_{2}$ and dissolved organic $\mathrm{C}$ in six of the rivers. They also found the lowest $\mathrm{N}_{2} \mathrm{O}$ values were observed at the highest $p \mathrm{CO}_{2}$ and lowest $\% \mathrm{O}_{2}$ levels, suggesting the removal of $\mathrm{N}_{2} \mathrm{O}$ by denitrification (Borges et al., 2015). In Lake Kivu (East Africa), the magnitude of $\mathrm{CO}_{2}$ emissions to the atmosphere seems to depend mainly on inputs of dissolved inorganic carbon from deep geothermal springs rather than on the lake metabolism (Borges et al., 2014).

\subsubsection{Greenhouse gas emissions from agricultural lands}

Agricultural GHG emissions in SSA are substantial, amounting to $26 \%$ of the continent's total GHG emissions (Valentini et al., 2014) compared to $8.4 \%$ of total GHG emissions in the USA (US EPA, 2016). Identifying controls on the emission of GHG from SSA agricultural land is challenging because both natural variations associated with climate and soil type and management factors including nutrients (particularly fertilization) and crop type affect GHG emissions.

\section{Croplands}

The effects of the amount and type of $\mathrm{N}$ input on $\mathrm{N}_{2} \mathrm{O}$ emissions in croplands have been studied in several locations (Table 4). In western Kenya, the rate of $\mathrm{N}$ fertilizer application ( 0 to $200 \mathrm{~kg} \mathrm{~N} \mathrm{ha}^{-1}$ ) on maize fields had no significant effect on $\mathrm{N}_{2} \mathrm{O}$ emissions (620 to $710 \mathrm{~g} \mathrm{~N}_{2} \mathrm{O}-\mathrm{N} \mathrm{ha}^{-1}$ for 99 days; Hickman et al., 2014). However, another study from western Kenya found a relationship between $\mathrm{N}$ input and $\mathrm{N}_{2} \mathrm{O}$ emissions that was best described by an exponential model with the largest impact on $\mathrm{N}_{2} \mathrm{O}$ emissions occurring when $\mathrm{N}$ inputs increased from 100 to $150 \mathrm{~kg} \mathrm{Nha}^{-1}$ (Hickman et al., 2015). An incubation study in Madagascar demonstrated that application of mixed urea and diammonium phosphate resulted in lower $\mathrm{N}_{2} \mathrm{O}$ emissions ( 28 vs. $55 \mathrm{ng} \mathrm{N}_{2} \mathrm{O}-\mathrm{N} \mathrm{g}^{-1} \mathrm{~h}^{-1}$ for 28 days, respectively) than a mixed application of urea and NPK fertilizer (Rabenarivo et al., 2014).

Incorporation of crop residues (tilling in crop residues following harvest) to the soil has frequently been proposed to increase soil fertility (Malhi et al., 2011); however, incorporation of crop residues also affects $\mathrm{CO}_{2}$ and $\mathrm{N}_{2} \mathrm{O}$ emissions (Table 3). In Tanzania, incorporation of maize straw and leaf residue into soil increased annual $\mathrm{CO}_{2}$ fluxes substantially (emissions rose from 2.5 to 4.0 and 2.4 to $3.4 \mathrm{MgC} \mathrm{ha}^{-1} \mathrm{yr}^{-1}$ for clay and sand soils, respectively; Sugihara et al., 2012), although a study in Madagascar showed that incorporation of rice-straw residue resulted in larger fluxes of $\mathrm{CO}_{2}$ but reduced $\mathrm{N}_{2} \mathrm{O}$ emissions due to $\mathrm{N}$ immobilization (Rabenarivo 
et al., 2014). In contrast, incorporation of Tithonia diversifolia (tithonia) leaves led to greater $\mathrm{N}_{2} \mathrm{O}$ emissions compared to urea application in maize fields in Kenya (Sommer et al., 2015; Kimetu et al., 2007). The higher $\mathrm{N}_{2} \mathrm{O}$ emissions after incorporation of Tithonia diversifolia were attributed to high levels of nitrate and available carbon in the soil caused by the application that subsequently enhanced denitrification rates. In incubation studies with cultivated soil from Ghana, $\mathrm{N}_{2} \mathrm{O}$ emissions were significantly higher from soils amended with low $\mathrm{C}: \mathrm{N}$ ratio clover residues compared to high $\mathrm{C}: \mathrm{N}$ ratio barley residues (Frimpong et al., 2012). Increasing the proportion of maize in a cowpeamaize residue significantly decreased $\mathrm{N}_{2} \mathrm{O}$ emissions compared to cowpea residue incorporation alone (Frimpong et al., 2011), again likely due to the higher $\mathrm{C}: \mathrm{N}$ ratio of the maize residue compared with the cowpea. Another incubation study with cultivated soil from Ghana showed that $\mathrm{N}_{2} \mathrm{O}$ emissions increased after incorporation of residues of three tropical plant species (Vigna unguiculata, Mucuna pruriens, and Leucaena leucocephala) and emissions were positively correlated with the $\mathrm{C}: \mathrm{N}$ ratio of the residue, and negatively correlated with residue polyphenol content, polyphenol: $\mathrm{N}$ ratio and (lignin + polyphenol) $: \mathrm{N}$ ratio (Frimpong and Baggs, 2010). It is rare for $\mathrm{N}_{2} \mathrm{O}$ emissions to be positively correlated with the $\mathrm{C}: \mathrm{N}$ ratio, and the authors of the study suggest that it was either because soil $\mathrm{C}$ was limiting denitrification rates or that release of $\mathrm{N}$ from the residues was slow (Frimpong and Baggs, 2010). The results demonstrate that the quality of residues (e.g., $\mathrm{C}: \mathrm{N}$ ratio, $\mathrm{N}$, lignin, and soluble polyphenol contents) affects GHG emissions and further studies are needed to clearly identify the relationship between them (Snyder et al., 2009; Mafongoya et al., 1997).

Adding an additional $\mathrm{N}$ (mineral or organic) when crop residues are incorporated into the soil could stimulate mineralization of crop residues, increase $\mathrm{N}$-use efficiency and produce higher yields (e.g., Garcia-Ruiz and Baggs, 2007; Table 4). It was found that application of mixed crop residue or manure and inorganic fertilizers resulted in different response of $\mathrm{CO}_{2}$ and $\mathrm{N}_{2} \mathrm{O}$ emissions. In maize (Zea mays L.) and winter wheat (Triticum aestivum L.) fields in Zimbabwe, application of inorganic fertilizer (ammonium nitrate, $\mathrm{NH}_{4} \mathrm{NO}_{3}-\mathrm{N}$ ) with manure increased $\mathrm{CO}_{2}$ emissions (26 to $73 \%$ ) compared to sole application of manure (Nyamadzawo et al., 2014a). However, the mixed application resulted in lower yield-scaled $\mathrm{N}_{2} \mathrm{O}$ emissions $\left(1.6-4.6 \mathrm{~g} \mathrm{~N}_{2} \mathrm{O} \mathrm{kg}^{-1}\right.$ yield), compared to sole application of inorganic fertilizer (6-14 $\mathrm{g} \mathrm{N}_{2} \mathrm{O} \mathrm{kg}^{-1}$ yield; Nyamadzawo et al., 2014a). Similarly, in a maize field in Zimbabwe, $\mathrm{N}_{2} \mathrm{O}$ emissions were lower after the application of composted manure and inorganic fertilizer $\left(\mathrm{NH}_{4} \mathrm{NO}_{3}-\mathrm{N}\right)$ compared to sole application of inorganic fertilizer. The same treatments, however, led to the opposite results for $\mathrm{CO}_{2}$ emissions (Mapanda et al., 2011). In Mali, pearl millet (Pennisetum glaucum) fields treated with both manure and inorganic fertilizer urea emitted significantly less $\mathrm{N}_{2} \mathrm{O}$ than plots receiving only urea fertilizer (Dick et al., 2008). The lower $\mathrm{N}_{2} \mathrm{O}$ emissions in soils amended with manure were attributed to the initial slow release and immobilization of mineral $\mathrm{N}$ and the consequently diminished pool of $\mathrm{N}$ available to be lost as $\mathrm{N}_{2} \mathrm{O}$ (Nyamadzawo et al., 2014a, b; Mapanda et al., 2011; Dick et al., 2008). In an incubation study with cultivated soils from Zimbabwe, Ghana, and Kenya, combining organic residue (maize, calliandra, and tithonia) and urea fertilizers decreased $\mathrm{N}_{2} \mathrm{O}$ emissions in coarse-textured soils but increased $\mathrm{N}_{2} \mathrm{O}$ emissions in finetextured soils due to the higher level of available $\mathrm{N}$ (Gentile et al., 2008).

The effects of crop type and management on GHG emissions have also been studied by several groups (Table 4). In Uganda, there were no significant differences in soil $\mathrm{CO}_{2}$ effluxes from different crops (lettuces, cabbages, beans; Koerber et al., 2009). However, in Zimbabwe, rape production resulted in greater $\mathrm{N}_{2} \mathrm{O}$ emissions $(0.64-0.93 \%$ of applied $\mathrm{N}$ was lost as $\left.\mathrm{N}_{2} \mathrm{O}\right)$ than tomatoes $(0.40-0.51 \%$ of applied $\mathrm{N}$ was lost as $\mathrm{N}_{2} \mathrm{O}$; Masaka et al., 2014). In Kenya and Tanzania, Rosenstock et al. (2016) studied fluxes in four crop types and found large variation of $\mathrm{CO}_{2}$ and $\mathrm{N}_{2} \mathrm{O}$ flux both within and between crop types depending on environmental conditions and management. In Madagascar, $\mathrm{N}_{2} \mathrm{O}$ emissions were not significantly affected by management practices such as direct seeding mulch-based cropping and traditional hand ploughing after harvesting (Chapuis-Lardy et al., 2009). However, the authors admitted the lack of difference between treatments may be partially due to the short duration of the experiment and suggested more complete monitoring to validate the observation. In highland Tanzanian maize fields, GHG fluxes were similar from soils under conventional and various conservation agriculture practices (Kimaro et al., 2016). However, when fluxes were yield-scaled the global warming potential $\left(\mathrm{Mg} \mathrm{CO}_{2}\right.$ eq. $\mathrm{Mg}$ grain $\left.^{-1}\right)$ was lower from fields with reduced tillage plus mulch and leguminous trees (2.1-3.1 $\mathrm{MgCO}_{2}$ eq. $\mathrm{Mg}_{\text {grain }}{ }^{-1}$ ) and from fields with reduced tillage plus mulch and nitrogen fertilizer (1.9-2.3 $\mathrm{Mg} \mathrm{CO}_{2}$ eq. $\mathrm{Mg}_{\text {grain }}{ }^{-1}$ ) compared to fields under conventional agriculture (1.9-8.3 $\mathrm{Mg} \mathrm{CO}_{2}$ eq. $\mathrm{Mg}_{\text {grain }}{ }^{-1}$; Kimaro et al., 2015). The results suggest that the effect of crop type and management on GHG emissions is difficult to predict and more research is needed to elucidate the relationship between crops, crop management, and GHG emissions.

Croplands were found to be both a sink and a source of $\mathrm{CH}_{4}$. In Burkina Faso, $\mathrm{CH}_{4}$ flux rates from croplands ranged from -0.67 to $0.70 \mathrm{~kg} \mathrm{CH}_{4}-\mathrm{Cha}^{-1} \mathrm{yr}^{-1}$ (Brümmer et al., 2009), while in the Republic of Congo, $\mathrm{CH}_{4}$ uptake was observed in cassava and peanut fields and a recently ploughed field (Delmas et al., 1991). However, cropped and fertilized dambos in Zimbabwe were consistently sources of $\mathrm{CH}_{4}$ (13.4 to $66.7 \mathrm{~kg} \mathrm{CH}_{4} \mathrm{ha}^{-1} \mathrm{yr}^{-1}$; Nyamadzawo et al., 2014b). 


\section{Grazing grassland}

We only found two studies reporting GHG emissions in pastoral grasslands, and there remains a serious gap in our understanding of GHG emissions in these systems. Thomas (2012) found that soil $\mathrm{CO}_{2}$ efflux from a Botswana grazing land was significantly higher in sandy soils where the biological soil crust (BSC) was removed and on calcrete where the BSC was buried under sand. The results indicated the importance of BSCs for C cycling in drylands and intensive grazing, which destroys BSCs through trampling and burial, will adversely affect $\mathrm{C}$ sequestration and storage (Thomas, 2012). Rosenstock et al. (2016) measured GHG fluxes from two pastures in western Kenya and found that $\mathrm{CO}_{2}$ emissions ranged from 13.4 to $15.9 \mathrm{Mg} \mathrm{CO}_{2} \mathrm{ha}^{-1} \mathrm{yr}^{-1}$, similar to levels found in the Amazon (Davidson et al., 2000).

\section{Rice paddies}

Rice paddies are well-known sources of $\mathrm{CH}_{4}$ (e.g., Linquist et al., 2012). Experiments measuring GHG emissions in rice paddies have been conducted in Kenya (Tyler et al., 1988) and Zimbabwe (Nyamadzawo et al., 2013). In Kenya, $\mathrm{CH}_{4}$ fluxes did not show any seasonal trend and did not indicate appreciable variability among two different strains of rice (Tyler et al., 1988). In Zimbabwe, intermittently saturated dambo rice paddies were a source of GHG and annual emissions (150-day growing season and $126 \mathrm{~kg}$ of applied $\mathrm{Nha}^{-1}$ ) were estimated as $2.7 \mathrm{MgCO}_{2} \mathrm{ha}^{-1} \mathrm{yr}^{-1}$, $12.5 \mathrm{~kg} \mathrm{CH}_{4} \mathrm{ha}^{-1}$, and $0.12 \mathrm{~kg} \mathrm{~N}_{2} \mathrm{O} \mathrm{ha}^{-1}$ (Nyamadzawo et al., 2013). The IPCC (2006) uses a $\mathrm{CH}_{4}$ emission factor of $1.30 \mathrm{~kg} \mathrm{CH}_{4} \mathrm{ha}^{-1} \mathrm{day}^{-1}$ for rice cultivation. The $\mathrm{CH}_{4}$ emissions in the dambo rice paddies referred to here are much lower than the IPCC estimate ( $195 \mathrm{~kg} \mathrm{CH}_{4} \mathrm{ha}^{-1}=1.3 \mathrm{~kg} \mathrm{CH}_{4} \mathrm{ha}^{-1} \mathrm{day}^{-1} \times 150$ days). The corresponding IPCC (2006) $\mathrm{N}_{2} \mathrm{O} \mathrm{EF}$ is $0.3 \%$ for rice cultivation, and thus the $\mathrm{N}_{2} \mathrm{O}$ emissions in the dambo rice paddies are also much lower than the IPCC estimate $\quad\left(0.40 \mathrm{~kg} \mathrm{~N}_{2} \mathrm{O}-\mathrm{N} \mathrm{ha}^{-1}=126 \mathrm{~kg} \mathrm{Nha}^{-1} \times 0.003\right.$; $\left.0.63 \mathrm{~kg} \mathrm{~N}_{2} \mathrm{Oha}^{-1}\right)$. These results suggest the potential for large deviations from expected emissions based on existing information.

\section{Vegetable gardens}

Greenhouse gas emissions from soils in vegetable gardens in peri-urban areas of Burkina Faso (Lompo et al., 2012) and Niger (Predotova et al., 2010) ranged from 73.3 to $132.0 \mathrm{MgCO}_{2} \mathrm{ha}^{-1} \mathrm{yr}^{-1}$ and 53.4 to $177.6 \mathrm{~kg} \mathrm{~N}_{2} \mathrm{O} \mathrm{ha}^{-1} \mathrm{yr}^{-1}$ (Tables 1 and $\mathrm{S} 1$ ).

In Burkina Faso, annual $\mathrm{CO}_{2}$ and $\mathrm{N}_{2} \mathrm{O}$ emissions from vegetable garden soils were 68 to 85 and 3 to $4 \%$ of total $\mathrm{C}$ and $\mathrm{N}$ input, respectively (Lompo et al., 2012). The $\mathrm{N}_{2} \mathrm{O}$ EFs (3 to $4 \%$ ) were higher than the IPCC default value of $1.0 \%$ for all cropping systems (IPCC, 2006) and the global
$\mathrm{N}_{2} \mathrm{O}$ EF of vegetable fields $(0.94 \%$; Rezaei Rashti et al., 2015). The high $\mathrm{N}_{2} \mathrm{O}$ EFs may be attributed to the excessive amount of applied $\mathrm{N}\left(2700-2800 \mathrm{~kg} \mathrm{~N} \mathrm{ha}^{-1} \mathrm{yr}^{-1}\right)$ to get high yields in vegetable gardens since surplus $\mathrm{N}$ will stimulate $\mathrm{N}_{2} \mathrm{O}$ production and inhibit biochemical $\mathrm{N}_{2} \mathrm{O}$ reduction (e.g., Shcherbak et al., 2014; Kim et al., 2013). In vegetable gardens of Niger, a simple plastic sheet roofing and addition of ground rock phosphate to stored ruminant manure decreased $\mathrm{N}_{2} \mathrm{O}$ gaseous losses by $50 \%$ in comparison to dung directly exposed to the sun (Predotova et al., 2010).

\section{Agroforestry}

Soil $\mathrm{CO}_{2}$ and $\mathrm{N}_{2} \mathrm{O}$ emissions from African agroforestry were $38.6 \mathrm{Mg} \mathrm{CO}_{2} \mathrm{ha}^{-1} \mathrm{yr}^{-1}$ and 0.2 to $26.7 \mathrm{~kg} \mathrm{~N}_{2} \mathrm{O} \mathrm{ha}^{-1} \mathrm{yr}^{-1}$, respectively (Tables 1 and $\mathrm{S} 1$ ).

Improving fallow with $\mathrm{N}$-fixing trees is a common agroforestry practice in several areas of Africa since it provides additional $\mathrm{N}$ to the soil that can be utilized by the subsequent cash crop (e.g., Makumba et al., 2007; Chikowo et al., 2004; Dick et al., 2001). However, the practice is also thought to increase $\mathrm{CO}_{2}$ and $\mathrm{N}_{2} \mathrm{O}$ emissions compared to conventional croplands (Table 4). Nitrous oxide emissions increased after incorporation of fallow residues and emissions were higher after incorporation of improved-fallow legume residues than natural-fallow residues (Baggs et al., 2006; Millar and Baggs, 2004; Millar et al., 2004). It was found that $\mathrm{N}_{2} \mathrm{O}$ emissions were positively correlated with residue $\mathrm{N}$ content (Baggs et al., 2006; Millar et al., 2004) and negatively correlated with polyphenol content and its protein binding capacity (Millar and Baggs, 2004), soluble C-to-N ratio (Millar and Baggs, 2005), and lignin content (Baggs et al., 2006). While high residue $\mathrm{N}$ content likely leads to more available soil $\mathrm{N}$ and consequently increased $\mathrm{N}_{2} \mathrm{O}$ production (Baggs et al., 2006; Millar and Baggs, 2005; Millar et al., 2004), polyphenols and lignins are both resistant to decomposition and could result in $\mathrm{N}$ immobilization resulting in less labile soil $\mathrm{N}$ and less $\mathrm{N}_{2} \mathrm{O}$ production (Baggs et al., 2006; Millar and Baggs, 2004). Therefore, there may be potential to reduce $\mathrm{N}_{2} \mathrm{O}$ emissions from agroforestry, but it may require ecological nutrient management (i.e., reduced inorganic fertilizer $\mathrm{N}$ inputs, accounting for $\mathrm{N}$ input from the legume trees; adding a $\mathrm{C}$ source such as a cover crop together with an $\mathrm{N}$ source) and rotation planning.

As in natural systems, $\mathrm{N}_{2} \mathrm{O}$ emissions from agroforestry are also affected by rainfall events. In an incubation experiment in Uganda, $\mathrm{N}_{2} \mathrm{O}$ emissions following simulated rainfall were at least 4 times larger for soils from under $\mathrm{N}$-fixing trees (Calliandra calothyrsus) compared to soils with non$\mathrm{N}$ fixing trees (Grevillea robusta; Dick et al., 2001). Similarly, in Mali, $\mathrm{N}_{2} \mathrm{O}$ emissions were around 6 times higher from improved fallow with $\mathrm{N}$-fixing trees (Gliricidia sepium and Acacia colei) following a simulated rainfall event compared with the emissions from soil under traditional fallow and continuous cultivation (Hall et al., 2006). In agroforestry 
home gardens in Sudan, $\mathrm{CO}_{2}$ and $\mathrm{N}_{2} \mathrm{O}$ fluxes were positively correlated with soil moisture (Goenster et al., 2015).

\subsubsection{Greenhouse gas emissions from land-use change}

Land-use change has been recognized as the largest source of GHG emission in Africa (Valentini et al., 2014). Conversion rates of African natural lands, including forest, grassland and wetland, to agricultural lands have increased in recent years (Gibbs et al., 2010; FAO, 2010). The dominant type of land-use change has been the conversion of forest to agriculture with average deforestation rates of $3.4 \mathrm{Mha} \mathrm{yr}^{-1}$ (FAOSTAT, 2014; Fig. 1). This land-use conversion results in an estimated additional release of $0.32 \pm 0.05 \times 10^{9} \mathrm{Mg} \mathrm{C} \mathrm{yr}^{-1}$ (Valentini et al., 2014) or $157.9 \pm 23.9 \times 10^{9} \mathrm{Mg} \mathrm{CO}_{2}$ eq. in 1765 to 2005 (Kim and Kirschbaum, 2015), higher than fossil fuel emissions for Africa (Valentini et al., 2014). Land-use change affects soil GHG emissions due to changes in vegetation, soil, hydrology, and nutrient management (e.g., Kim and Kirschbaum, 2015) and the effects of land-use change on soil GHG emissions have been observed in African woodlands and savannah. Clearing and converting woodlands to croplands increased soil emissions of $\mathrm{CO}_{2}, \mathrm{CH}_{4}$, and $\mathrm{N}_{2} \mathrm{O}$ (Mapanda et al., 2012), and soil $\mathrm{CO}_{2}$ emissions from the converted croplands were higher than Eucalyptus plantations established in former natural woodlands (Mapanda et al., 2010). Changes in soil $\mathrm{CO}_{2}$ efflux after afforestation of a tropical savannah with Eucalyptus were mostly driven by the rapid decomposition of savannah residues and the increase in Eucalyptus rhizospheric respiration (Nouvellon et al., 2012).

\subsection{Suggested future research}

Despite an increasing number of published estimates of GHG emissions in the last decade, there remains a high degree of uncertainty about the contribution of AFOLU to emissions in SSA (Table 5). To address this and reduce the uncertainty surrounding the estimates, additional GHG emission measurements that fully capture seasonal and annual variations across natural ecosystems and agricultural lands throughout SSA are urgently required. Identifying controlling factors and their effects on GHG fluxes is a pre-requisite to enhancing our understanding of efflux mechanisms and a necessary step towards scaling up the field-scale data to landscape, national, and continental scales (Table 5). It is important to know how GHG fluxes can be affected by management practices and natural events such as logging (e.g., Yashiro et al., 2008), thinning (e.g., Yohannes et al., 2013), storms (e.g., Vargas, 2012), pest outbreaks (e.g., Reed et al., 2014), fires (e.g., Andersson et al., 2004), and woody shrub encroachment (e.g., Smith and Johnson, 2004) in natural terrestrial systems and changing discharge (e.g., Wang et al., 2013) and water table (e.g., Yang et al., 2013) in aquatic systems. It is also important in agricultural lands to know how GHG fluxes are affected by management factors such as soil compaction (e.g., Ball et al., 1999), tillage (e.g., Sheehy et al., 2013), removal of crop residues (Jin et al., 2014), incorporation of crop residues and synthetic fertilizer (e.g., Nyamadzawo et al., 2014a), N input (whether organic or inorganic; e.g., Hickman et al., 2015), and crop type (e.g., Masaka et al., 2014). However, because management and soil physical-chemical interactions cause different responses in soil GHG emissions (e.g., Pelster et al., 2012), it is critical to measure these interaction effects in the African context. The effect of predicted climatic change in Africa such as increased temperature (e.g., Dijkstra et al., 2012), changing rainfall patterns (e.g., Hall et al., 2006), increase in droughts incidence (e.g., Berger et al., 2013), rewetting effects (e.g., Kim et al., 2012b), and increased atmospheric $\mathrm{CO}_{2}$ concentration (e.g., Lane et al., 2013) also require further testing using laboratory and field experiments. Future research should consider the wider GHG budget of agriculture and include all the various (non-soil) components such as fuel use, as well as embodied emissions in chemical inputs.

Where possible, studies should seek to identify and separate the processes contributing to efflux of soil $\mathrm{CO}_{2}$ (e.g., autotrophic and heterotrophic sources), $\mathrm{CH}_{4}$ (e.g., methanogenesis and methanotrophy), and $\mathrm{N}_{2} \mathrm{O}$ (e.g., nitrification, denitrification, and nitrifier denitrification) and link new knowledge of microbial communities (e.g., functional gene abundance) to GHG emissions rates. This is important because the consequences of increasing GHG emissions depend on the mechanism responsible. For example, if greater soil $\mathrm{CO}_{2}$ efflux is primarily due to autotrophic respiration from plant roots, then it simply reflects greater plant growth. If, however, it is due to heterotrophic microbial respiration of soil organic carbon, then it represents a depletion of soil organic matter and a net transfer of $\mathrm{C}$ from soil to the atmosphere. Currently, there are very few studies that differentiate these sources, making it impossible to truly determine the consequences and implications on changes in soil GHG efflux.

Land-use change has been recognized as the largest source of GHG emission in Africa (Valentini et al., 2014). Hence, various types of conversion from natural lands to different land-use types should be assessed to know how these changes may affect the GHG budget (e.g., Kim and Kirschbaum, 2015). The focus of the assessment should be on deforestation and wetland drainage, followed by a conversion to agricultural lands, since they are dominant types of land-use change in Africa (Valentini et al., 2014).

Throughout the study, we identified various trade-offs including increased $\mathrm{CO}_{2}$ emission following forest thinning management, increased GHG emissions in land-use changes, very high $\mathrm{N}_{2} \mathrm{O}$ emissions in vegetable gardens due to excessive $\mathrm{N}$ input to get high yields, increased $\mathrm{CO}_{2}$ and $\mathrm{N}_{2} \mathrm{O}$ emission in incorporation of crop residues to the soil and agroforestry practices, and exponentially increased $\mathrm{N}_{2} \mathrm{O}$ emission and yield-scaled $\mathrm{N}_{2} \mathrm{O}$ emissions in excessive $\mathrm{N}$ input. More work is needed, however, before we have a clear picture of the net impact of the tradeoffs and drivers. 
Table 5. Summary of status of knowledge of greenhouse gas emission processes, control factors, estimation, and model prediction.

\begin{tabular}{|c|c|c|c|c|c|c|c|c|c|}
\hline & \multicolumn{3}{|c|}{$\mathrm{CO}_{2}$} & \multicolumn{3}{|c|}{$\mathrm{N}_{2} \mathrm{O}$} & \multicolumn{3}{|c|}{$\mathrm{CH}_{4}$} \\
\hline & $\begin{array}{l}\text { Processes \& } \\
\text { control factors }\end{array}$ & $\begin{array}{l}\text { Annual flux } \\
\text { estimate }\end{array}$ & $\begin{array}{c}\text { Model } \\
\text { prediction }\end{array}$ & $\begin{array}{l}\text { Processes \& } \\
\text { control factors }\end{array}$ & $\begin{array}{l}\text { Annual flux } \\
\text { estimate }\end{array}$ & $\begin{array}{l}\text { Model } \\
\text { prediction }\end{array}$ & $\begin{array}{l}\text { Processes \& } \\
\text { control factors }\end{array}$ & $\begin{array}{l}\text { Annual flux } \\
\text { estimate }\end{array}$ & $\begin{array}{c}\text { Model } \\
\text { prediction }\end{array}$ \\
\hline Forest/plantation/woodland & 1 & 2 & 4 & 3 & 3 & 4 & 3 & 3 & 4 \\
\hline Savannah & 2 & 3 & 4 & 3 & 4 & 4 & 3 & 4 & 4 \\
\hline Aquatic systems & 2 & 3 & 4 & 3 & 3 & 4 & 2 & 3 & 4 \\
\hline Cropland & 2 & 3 & 4 & 2 & 2 & 4 & 3 & 4 & 4 \\
\hline Agroforestry & 3 & 4 & 4 & 2 & 3 & 4 & 4 & 4 & 4 \\
\hline Vegetable gardens & 3 & 4 & 4 & 3 & 4 & 4 & 4 & 4 & 4 \\
\hline Rice field & 3 & 4 & 4 & 3 & 4 & 4 & 4 & 4 & 4 \\
\hline Grazing grassland & 3 & 4 & 4 & 4 & 4 & 4 & 4 & 4 & 4 \\
\hline
\end{tabular}

\subsection{Strategic approaches for data acquisition}

A strategic plan for acquisition of soil GHG emission data in sub-Saharan Africa is required. The success of any plan is dependent on long-term investment, stakeholder involvement, technical skill, and supporting industries, which have not always been available in the region (Olander et al., 2013; Franks and Hadingham, 2012). A major challenge is to address the lack of consistency in the various methodologies used to quantify GHG emissions (Rosenstock et al., 2013). Relatively low cost and simple techniques can be used to determine GHG emission estimates in the first instance. Soil $\mathrm{CO}_{2}$ fluxes can be quantified with a soda lime method (Tufekcioglu et al., 2001; Cropper et al., 1985; Edwards, 1982) or an infrared gas analyzer (Bastviken et al., 2015; Verchot et al., 2008; Lee and Jose, 2003), and these do not require advanced technology or high levels of resource to undertake. Later, other GHG such as $\mathrm{N}_{2} \mathrm{O}$ and $\mathrm{CH}_{4}$ fluxes in addition to $\mathrm{CO}_{2}$ flux can be measured with more advanced technology (e.g., gas chromatography, photoacoustic spectroscopy, or laser gas analyzers). Initially, the measurement can be conducted using manual gas chambers with periodical sampling frequencies. The sampling interval can be designed so that it is appropriate to the particular type of land use or ecosystem, management practices, and/or for capturing the effects of episodic events (e.g., Parkin, 2008). For example, GHG measurement should be more during potentially high GHG emission periods following tillage and fertilizer applications and rewetting by natural rainfalls or irrigation. With more advanced technology and utilization of automatic chamber systems, measurements can be conducted at a much higher frequency with relative ease.

In order for the challenges associated with improving our understanding of GHG emissions from African soils, it is critical to establish networks of scientists and scientific bodies both within Africa and across the world. Good communication and collaboration between field researchers and the modeling community should also be established during the initial stages of research, so results obtained from field scientists can be effectively used for model development and to generate hypotheses to be tested in the field and laboratory (de Bruijn et al., 2009).

Furthermore, lessons learned from scientific experiments can only really be successfully implemented by farmers if local stakeholders are involved from the start and throughout (see, for example, Stringer et al., 2012). Interviews, focusgroups, on-site or farm demonstrations, local capacity building training, local farmers, and extension staff can all improve dialogue and understanding between local communities and scientists, ultimately improving the likelihood of successful GHG emission and mitigation strategies. These will equip local researchers and stakeholders (including farmers and extension staff) with state-of-the-art methodologies and help motivate them to develop their GHG mitigation measures and assist them in understanding their roles and contributions to global environmental issues. Moreover, data acquisition will be determined not only by technical but also by sociopolitical (and economic) barriers in sub-Saharan Africa. These problems not only affect data acquisition but are also the driving forces for GHG emissions due to landuse change events.

\section{Conclusions}

This paper synthesizes the available data on GHG emissions from African agricultural and natural lands. Emissions of $\mathrm{CO}_{2}, \mathrm{CH}_{4}$, and $\mathrm{N}_{2} \mathrm{O}$ in a variety of environments (forests, savannahs, termite mounds, salt pans, agricultural areas, and water bodies) were considered. Two broad conclusions can be drawn from the work. The first one is that African natural and agricultural lands may be a significant source of GHG and that the emissions may increase through land-use change and management strategies. Secondly, there are huge research gaps. Africa is a vast continent, with a multitude of land uses, climates, soils, and ecosystems. Field-based data on soil GHG emissions from many areas, soil types, and environments are extremely sparse, and as a result our understanding of Africa's contribution to global GHG emissions remains incomplete and highly uncertain. There is an urgent need to develop and agree on a strategy for addressing this 
data gap. The strategy needs to involve identifying priorities for data acquisition, utilizing appropriate technologies, and establishing networks and collaboration.

\section{Data availability}

We have created a blog entitled "Greenhouse gas emissions in Africa: study summary and database" (http://ghginafrica. blogspot.com/) and an open-access database, which can be modified by the users, entitled "Soil greenhouse gas emissions in Africa database" (linked in the blog) based on this review. In the blog, we have posted a technical summary of each section of this review, where comments can be left under the posts. The database contains detailed information on the studies reported on GHG emissions, such as ecosystem and land-use types, location, climate, vegetation type, crop type, fertilizer type, $\mathrm{N}$ input rate, soil properties, GHGs emission measurement periods, $\mathrm{N}_{2} \mathrm{O} E F$, and corresponding reference. The database is hosted in web-based spreadsheets and is easily accessible and modified. The authors do not have any relationship with the companies currently being used to host the blog or databases.

\section{The Supplement related to this article is available online at doi:10.5194/bg-13-4789-2016-supplement.}

Acknowledgements. We are grateful for the numerous researchers and technicians who provided invaluable data. It is impossible to cite all the references due to limited space allowed and we apologize for the authors whose work has not been cited. We are also grateful to Benjamin Bond-Lamberty and Rodrigo Vargas for insightful comments, Luis Lassaletta for guiding us with $\mathrm{N}$ application rates in Africa, and Antony Smith for creating maps showing study sites. Alberto Sanz-Cobena gratefully acknowledges the Spanish Ministry of Science and Innovation and the Autonomous Community of Madrid for their economic support through the NEREA project (AGL2012-37815- C05-01, AGL2012-37815C05-04), the Agrisost Project (S2013/ABI-2717), and the FACCE JPI MACSUR project. Dong-Gill Kim acknowledges support from Research and Development Office, Wondo Genet College, and the IAEA Coordinated Research Project (CRP D1 50.16). David Pelster and Todd S. Rosenstock would like to thank the CGIAR Research Program on Climate Change, Agriculture, and Food Security and its Standard Assessment of Mitigation Potential and Livelihoods in Smallholder Systems (SAMPLES) Programme for technical and financial support.

Edited by: M. Weintraub

Reviewed by: three anonymous referees

\section{References}

Andersson, M., Michelsen, A., Jensen, M., and Kjøller, A.: Tropical savannah woodland: Effects of experimental fire on soil microorganisms and soil emissions of carbon dioxide, Soil Biol. Biochem., 36, 849-858, 2004.

Baggs, E., Chebii, J., and Ndufa, J.: A short-term investigation of trace gas emissions following tillage and no-tillage of agroforestry residues in western Kenya, Soil Till. Res., 90, 69-76, 2006.

Ball, B. C., Scott, A., and Parker, J. P.: Field $\mathrm{N}_{2} \mathrm{O}, \mathrm{CO}_{2}$ and $\mathrm{CH}_{4}$ fluxes in relation to tillage, compaction and soil quality in Scotland, Soil Till. Res., 53, 29-39, 1999.

Barton, L., Wolf, B., Rowlings, D., Scheer, C., Kiese, R., Grace, P., Stefanova, K., and Butterbach-Bahl, K.: Sampling frequency affects estimates of annual nitrous oxide fluxes, Sci. Rep., 5, 15912, doi:10.1038/srep15912, 2015.

Bastviken, D., Sundgren, I., Natchimuthu, S., Reyier, H., and Gålfalk, M.: Technical Note: Cost-efficient approaches to measure carbon dioxide $\left(\mathrm{CO}_{2}\right)$ fluxes and concentrations in terrestrial and aquatic environments using mini loggers, Biogeosciences, 12, 3849-3859, doi:10.5194/bg-12-3849-2015, 2015.

Bateganya, N. L., Mentler, A., Langergraber, G., Busulwa, H., and Hein, T.: Carbon and nitrogen gaseous fluxes from subsurface flow wetland buffer strips at mesocosm scale in east Africa, Ecol. Eng., 85, 173-184, 2015.

Berger, S., Jung, E., Köpp, J., Kang, H., and Gebauer, G.: Monsoon rains, drought periods and soil texture as drivers of soil $\mathrm{N}_{2} \mathrm{O}$ fluxes - Soil drought turns East Asian temperate deciduous forest soils into temporary and unexpectedly persistent $\mathrm{N}_{2} \mathrm{O}$ sinks, Soil Biol. Biochem., 57, 273-281, 2013.

Birch, H. F.: Mineralisation of plant nitrogen following alternate wet and dry conditions, Plant Soil, 20, 43-49, 1964.

Bombelli, A., Henry, M., Castaldi, S., Adu-Bredu, S., Arneth, A., de Grandcourt, A., Grieco, E., Kutsch, W. L., Lehsten, V., Rasile, A., Reichstein, M., Tansey, K., Weber, U., and Valentini, R.: An outlook on the Sub-Saharan Africa carbon balance, Biogeosciences, 6, 2193-2205, doi:10.5194/bg-6-2193-2009, 2009.

Bond-Lamberty, B. and Thomson, A. M.: Temperature-associated increases in the global soil respiration record, Nature, 464, 579582, 2010.

Borges, A. V., Abril, G., Delille, B., Descy, J.P., and Darchambeau, F.: Diffusive methane emissions to the atmosphere from Lake Kivu (Eastern Africa), J. Geophys. Res, 116, G03032, doi:10.1029/2011JG001673, 2011.

Borges, A. V., Morana, C., Bouillon. S., Servais, P., Descy, J.-P., and Darchambeau, F.: Carbon cycling of Lake Kivu (East Africa): net autotrophy in the epilimnion and emission of $\mathrm{CO}_{2}$ to the atmosphere sustained by geogenic inputs, PLoS one, 9, e109500, doi:10.1371/journal.pone.0109500, 2014.

Borges, A. V., Darchambeau, F., Teodoru, C. R., Marwick, T. R., Tamooh, F., Geeraert, N., Omengo, F. O., Guerin, F., Lambert, T., Morana, C., Okuku, E., and Bouillon, S.: Globally significant greenhouse-gas emissions from African inland waters, Nat. Geosci., 8, 637-642, doi:10.1038/ngeo2486, 2015.

Bouillon, S., Yambélé, A., Spencer, R. G. M., Gillikin, D. P., Hernes, P. J., Six, J., Merckx, R., and Borges, A. V.: Organic matter sources, fluxes and greenhouse gas exchange in the Oubangui River (Congo River basin), Biogeosciences, 9, 2045-2062, doi:10.5194/bg-9-2045-2012, 2012. 
Bouwman, A. F., Beusen, A. H. W., and Billen, G.: Human alteration of the global nitrogen and phosphorus soil balances for the period 1970-2050, Global Biogeochem. Cy., 23, GB0A04, doi:10.1029/2009GB003576, 2009.

Bouwman, L., Goldewijk, K. K., Van Der Hoek, K. W., Beusen, A. H. W., Van Vuuren, D. P., Willems, J., Rufino, M. C., and Stehfest, E.: Exploring global changes in nitrogen and phosphorus cycles in agriculture induced by livestock production over the 1900-2050 period, P. Natl. Acad. Sci. USA, 110, 20882-20887, doi:10.1073/pnas.1012878108, 2013.

Brümmer, C., Papen, H., Wassmann, R., and Brüggemann, N.: Fluxes of $\mathrm{CH}_{4}$ and $\mathrm{CO}_{2}$ from soil and termite mounds in south Sudanian savanna of Burkina Faso (West Africa), Global Biogeochem. Cy., 23, GB1001, doi:10.1029/2008GB003237, 2009.

Brunet, F., Dubois, K., Veizer, J., Nkoue Ndondo, G. R., Ndam Ngoupayou, J. R., Boeglin, J. L., and Probst, J. L.: Terrestrial and fluvial carbon fluxes in a tropical watershed: Nyong basin, Cameroun, Chem. Geol., 2, 563-572, 2009.

Caquet, B., De Grandcourt, A., Thongo M'bou, A., Epron, D., Kinana, A., Saint André, L., and Nouvellon, Y.: Soil carbon balance in a tropical grassland: Estimation of soil respiration and its partitioning using a semi-empirical model, Agr. Forest. Meteorol., 158-159, 71-79, 2012.

Castaldi, S., de Grandcourt, A., Rasile, A., Skiba, U., and Valentini, R.: $\mathrm{CO}_{2}, \mathrm{CH}_{4}$ and $\mathrm{N}_{2} \mathrm{O}$ fluxes from soil of a burned grassland in Central Africa, Biogeosciences, 7, 3459-3471, doi:10.5194/bg7-3459-2010, 2010.

Chapuis-Lardy, L., Metay, A., Martinet, M., Rabenarivo, M., Toucet, J., Douzet, J. M., Razafimbelo, T., Rabeharisoa, L., and Rakotoarisoa, J.: Nitrous oxide fluxes from malagasy agricultural soils, Geoderma, 148, 421-427, 2009.

Chikowo, R., Mapfumo, P., Nyamugafata, P., and Giller, K. E.: Mineral $n$ dynamics, leaching and nitrous oxide losses under maize following two-year improved fallows on a sandy loam soil in Zimbabwe, Plant Soil, 259, 315-330, 2004.

Ciais, P., Bombelli, A., Williams, M., Piao, S. L., Chave, J., Ryan, C. M., Henry, M., Brender, P., and Valentini, R.: The Carbon Balance of Africa: Synthesis of Recent Research Studies, Philos. T. R. Soc. A, 269, 2038-2057, 2011.

Cropper Jr., W., Ewel, K.C., and Raich, J.: The measurement of soil $\mathrm{CO}_{2}$ evolution in situ, Pedobiologia, 28, 35-40, 1985.

Davidson, E. A., Verchot, L. V., Cattanio, J. H., Ackerman, I. L., and Carvalho, J.: Effects of soil water content on soil respiration in forests and cattle pastures of eastern Amazonia, Biogeochemistry, 48, 53-69, 2000.

de Bruijn, A. M. G., Butterbach-Bahl, K., Blagodatsky, S., and Grote, R.: Model evaluation of different mechanisms driving freeze-thaw $\mathrm{N}_{2} \mathrm{O}$ emissions, Agric. Ecosyst. Environ., 133, 196207, 2009.

Delmas, R. A., Marenco, A., Tathy, J. P., Cros, B., and Baudet, J. G. R.: Sources and sinks of methane in African savanna. $\mathrm{CH}_{4}$ emissions from biomass burning, J. Geophys. Res., 96, 72877299, 1991.

DelSontro, T., Kunz, M. J., Kempter, T., Wüest, A., Wehrli, B., and Senn, D. B.: Spatial heterogeneity of methane ebullition in a large tropical reservoir, Environ. Sci. Technol., 45, 9866-9873, doi:10.1021/es2005545, 2011.

Díaz-Pinés, E., Schindlbacher, A., Godino, M., Kitzler, B., Jandl, R., Zechmeister-Boltenstern, S., and Rubio, A.: Effects of tree species composition on the $\mathrm{CO}_{2}$ and $\mathrm{N}_{2} \mathrm{O}$ efflux of a Mediterranean mountain forest soil, Plant Soil, 384, 243-257, 2014.

Dick, J., Skiba, U., and Wilson J.: The effect of rainfall on NO and $\mathrm{N}_{2} \mathrm{O}$ emissions from Ugandan agroforest soils, Phyton, 41, 7380, 2001.

Dick, J., Skiba, U., Munro, R., and Deans, D.: Effect of N-fixing and non n-fixing trees and crops on $\mathrm{NO}$ and $\mathrm{N}_{2} \mathrm{O}$ emissions from Senegalese soils, J. Biogeogr., 33, 416-423, 2006.

Dick, J., Kaya, B., Soutoura, M., Skiba, U., Smith, R., Niang, A., and Tabo, R.: The contribution of agricultural practices to nitrous oxide emissions in semi-arid Mali, Soil Use Manage., 24, 292 301, 2008.

Dijkstra, F. A., Prior, S. A., Runion, G. B., Torbert, H. A., Tian, H., $\mathrm{Lu}, \mathrm{C}$., and Venterea, R. T.: Effects of elevated carbon dioxide and increased temperature on methane and nitrous oxide fluxes: evidence from field experiments, Front. Ecol. Environ., 10, 520527, 2012.

Dutaur, L. and Verchot, L. V.: A global inventory of the soil $\mathrm{CH}_{4}$ sink, Global Biogeoche. Cy., 21, GB4013, doi:10.1029/2006gb002734, 2007.

Edwards, N.: The use of soda-lime for measuring respiration rates in terrestrial systems, Pedobiologia, 23, 321-330, 1982.

Epron, D., Nouvellon, Y., Roupsard, O., Mouvondy, W., Mabiala, A., Saint-André, L., Joffre, R., Jourdan, C., Bonnefond, J.-M., Berbigier, P., and Hamel, O.: Spatial and temporal variations of soil respiration in a eucalyptus plantation in Congo, Forest Ecol. Manage., 202, 149-160, 2004.

Epron, D., Nouvellon, Y., Mareschal, L., e Moreira, R. M., Koutika, L.-S., Geneste, B., Delgado-Rojas, J. S., Laclau, J.-P., Sola, G., and de Moraes Goncalves, J. L.: Partitioning of net primary production in eucalyptus and acacia stands and in mixed-species plantations: Two case-studies in contrasting tropical environments, Forest Ecol. Manage., 301, 102-111, 2013.

Fan, Z., Neff, J. C., and Hanan, N. P.: Modeling pulsed soil respiration in an African savanna ecosystem, Agr. Forest. Meteorol. 200, 282-292, 2015.

FAO: Global Forest Resources Assessment 2010, FAO Forestry Paper 163, Food and Agriculture Organization of the United Nations, Rome, 340 pp., available at: http://www.fao.org/forestry/ fra/fra2010/en/ (last access: 1 October 2015), 2010.

FAOSTAT: Food and agriculture organization of the United Nations, http://faostat.fao.org/site/377/default.aspx\#ancor, last access: 1 October 2015.

Franks, J. R. and Hadingham, B.: Reducing greenhouse gas emissions from agriculture: Avoiding trivial solutions to a global problem, Land Use Policy, 29, 727-736, 2012.

Frimpong, K. A. and Baggs, E. M.: Do combined applications of crop residues and inorganic fertilizer lower emission of $\mathrm{N}_{2} \mathrm{O}$ from soil?, Soil Use Manage., 26, 412-424, 2010.

Frimpong, K. A., Yawson, D. O., Baggs, E. M., and Agyarko, K.: Does incorporation of cowpea-maize residue mixes influence nitrous oxide emission and mineral nitrogen release in a tropical luvisol?, Nutr. Cycl. Agroecosys., 91, 281-292, 2011.

Frimpong, K. A., Yawson, D. O., Agyarko, K., and Baggs, E. M.: $\mathrm{N}_{2} \mathrm{O}$ emission and mineral $\mathrm{N}$ release in a tropical acrisol incorporated with mixed cowpea and maize residues, Agron., 2, 167186, 2012. 
Garcia-Ruiz, R. and Baggs, E.: $\mathrm{N}_{2} \mathrm{O}$ emission from soil following combined application of fertiliser-N and ground weed residues, Plant Soil, 299, 263-274, 2007.

Gentile, R., Vanlauwe, B., Chivenge, P., and Six, J.: Interactive effects from combining fertilizer and organic residue inputs on nitrogen transformations, Soil Biol. Biochem., 40, 2375-2384, 2008.

Gharahi Ghehi, N., Werner, C., Cizungu Ntaboba, L., Mbonigaba Muhinda, J. J., Van Ranst, E., Butterbach-Bahl, K., Kiese, R., and Boeckx, P.: Spatial variations of nitrogen trace gas emissions from tropical mountain forests in Nyungwe, Rwanda, Biogeosciences, 9, 1451-1463, doi:10.5194/bg-9-1451-2012, 2012.

Gharahi Ghehi, N., Werner, C., Hufkens, K., Kiese, R., Van Ranst, E., Nsabimana, D., Wallin, G., Klemedtsson, L., ButterbachBahl, K., and Boeckx, P.: $\mathrm{N}_{2} \mathrm{O}$ and $\mathrm{NO}$ emission from the Nyungwe tropical highland rainforest in Rwanda, Geoderma Regional, 2-3, 41-49, 2014.

Gibbs, H. K., Ruesch, A. S., Achard, F., Clayton, M. K., Holmgren, P., Ramankutty, N., and Foley, J. A.: Tropical forests were the primary sources of new agricultural land in the 1980s and 1990s, P. Natl. Acad. Sci. USA, 107, 16732-16737, 2010.

Goenster, S., Wiehle, M., Predotova, M., Gebauer, J., Ali, A. M., and Buerkert, A.: Gaseous emissions and soil fertility of homegardens in the Nuba Mountains, Sudan, J. Plant Nutr. Soil Sci., $178,413-424,2015$.

Gondwe, M. J. and Masamba, W. R.: Spatial and temporal dynamics of diffusive methane emissions in the Okavango delta, northern Botswana, Africa, Wetlands Ecol. Manage., 22, 63-78, 2014.

Hall, N. M., Kaya, B., Dick, J., Skiba, U., Niang, A., and Tabo, R.: Effect of improved fallow on crop productivity, soil fertility and climate-forcing gas emissions in semi-arid conditions, Biol. Fert. Soils, 42, 224-230, 2006.

Hanson, R. S. and Hanson, T. E.: Methanotrophic bacteria, Microbiol. Molecular Biol. Rev., 60, 439-471, 1996.

Hickman, J. E., Havlikova, M., Kroeze, C., and Palm, C. A.: Current and future nitrous oxide emissions from African agriculture, Curr. Opinion Environ. Sustain., 3, 370-378, 2011.

Hickman, J. E., Palm, C., Mutuo, P., Melillo, J., and Tang, J.: Nitrous oxide $\left(\mathrm{N}_{2} \mathrm{O}\right)$ emissions in response to increasing fertilizer addition in maize (Zea mays L.) agriculture in western Kenya, Nutr. Cycl. Agroecosys., 100, 177-187, 2014.

Hickman, J. E., Tully, K. L., Groffman, P. M., Diru, W., and Palm, C. A. C. J. G.: A potential tipping point in tropical agriculture: Avoiding rapid increases in nitrous oxide fluxes from agricultural intensification in Kenya, J. Geophys. Res., 12, 938-951, doi:10.1002/2015JG002913, 2015.

IPCC: Intergovernmental Panel on Climate Change: Guidelines for national greenhouse gas inventories, available at: http://www. ipcc-nggip.iges.or.jp/public/2006gl/index.html, (last access: 27 March 2015), Geneva, Switzerland, 2006.

IPCC: Summary for policymakers, in: Climate Change 2014, Mitigation of Climate Change, contribution of Working Group III to the Fifth Assessment Report of the Intergovernmental Panel on Climate Change, edited by: Edenhofer, O., Pichs-Madruga, R., Sokona, Y., Farahani, E., Kadner, S., Seyboth, K., Adler, A., Baum, I., Brunner, S., Eickemeier, P., Kriemann, B., Savolainen, J., Schlomer, S., von Stechow, C., Zwickel, T., and Minx, J. C., Cambridge University Press, Cambridge, UK and New York, NY, USA, 1-30, 2014.
Iqbal, J., Castellano, M. J., and Parkin, T. B.: Evaluation of photoacoustic infrared spectroscopy for simultaneous measurement of $\mathrm{N}_{2} \mathrm{O}$ and $\mathrm{CO}_{2}$ gas concentrations and fluxes at the soil surface, Glob. Change Biol., 19, 327-336, 2013.

Jin, V. L., Baker, J. M., Johnson, J. M. F., Karlen, D. L., Lehman, R. M., Osborne, S. L., Sauer, T. J., Stott, D. E., Varvel, G. E., and Venterea, R. T.: Soil greenhouse gas emissions in response to corn stover removal and tillage management across the us corn belt, BioEnerg. Res., 7, 517-527, 2014.

Kim, D.-G.: Estimation of net gain of soil carbon in a nitrogenfixing tree and crop intercropping system in sub-Saharan Africa: Results from re-examining a study, Agroforest. Sys., 86, 175$184,2012$.

Kim, D.-G. and Kirschbaum, M. U.: The effect of land-use change on the net exchange rates of greenhouse gases: A compilation of estimates, Agr. Ecosyst. Environ., 208, 114-126, 2015.

Kim, D.-G., Mu, S., Kang, S., and Lee, D.: Factors controlling soil $\mathrm{CO}_{2}$ effluxes and the effects of rewetting on effluxes in adjacent deciduous, coniferous, and mixed forests in Korea, Soil Biol. Biochem., 42, 576-585, 2010.

Kim, D.-G., Vargas, R., Bond-Lamberty, B., and Turetsky, M. R.: Effects of soil rewetting and thawing on soil gas fluxes: a review of current literature and suggestions for future research, Biogeosciences, 9, 2459-2483, doi:10.5194/bg-9-2459-2012, 2012.

Kim, D.-G., Hernandez-Ramirez, G., and Giltrap, D.: Linear and nonlinear dependency of direct nitrous oxide emissions on fertilizer nitrogen input: A meta-analysis, Agr. Ecosyst. Environ., 168, 53-65, 2013.

Kim, Y. S., Makoto, K., Takakai, F., Shibata, H., Satomura, T., Takagi, K., Hatano, R., and Koike, T.: Greenhouse gas emissions after a prescribed fire in white birch-dwarf bamboo stands in northern Japan, focusing on the role of charcoal, Eur J. Forest Res., 130, 1031-1044, 2011.

Kimaro, A., Mpanda, M., Rioux, J., Aynekulu, E., Shaba, S., Thiong'o, M., Mutuo, P., Abwanda, S., Shepherd, K., Neufeldt, H., and Rosenstock, T.: Is conservation agriculture "climatesmart" for maize farmers in the highlands of Tanzania?, Nutr. Cycl. Agroecosys., 105, 217-228, 10.1007/s10705-015-9711-8, 2016.

Kimetu, J., Mugendi, D., Bationo, A., Palm, C., Mutuo, P., Kihara, J., Nandwa, S., and Giller, K.: Partial balance of nitrogen in a maize cropping system in humic nitisol of Central Kenya, Nutr. Cycl. Agroecosys., 76, 261-270, 2007.

Knowles, R.: Denitrification, Microbiol. Rev., 46, 43-70, 1982.

Koerber, G. R., Edwards-Jones, G., Hill, P. W., Nyeko, P., York, E. H., and Jones, D. L.: Geographical variation in carbon dioxide fluxes from soils in agro-ecosystems and its implications for lifecycle assessment, J. Appl. Ecol., 46, 306-314, 2009.

Koné, Y. J. M., Abril, G., Kouadio, K. N., Delille, B., and Borges, A. V.: Seasonal variability of carbon dioxide in the rivers and lagoons of Ivory Coast (West Africa), Estuar. Coast., 32, 246260, 2009.

Kowalchuk, G. A. and Stephen, J. R.: Ammonia-oxidizing bacteria: A model for molecular microbial ecology, Annu. Rev. Microbiol., 55, 485-529, 2001.

Kulmala, L., Aaltonen, H., Berninger, F., Kieloaho, A.-J., Levula, J., Bäck, J., Hari, P., Kolari, P., Korhonen, J. F. J., Kulmala, M., Nikinmaa, E., Pihlatie, M., Vesala, T., and Pumpanen, J.: Changes in biogeochemistry and carbon fluxes in a boreal forest 
after the clear-cutting and partial burning of slash, Agr. Forest. Meteorol., 188, 33-44, 2014.

Lamade, E., Djegui, N., and Leterme, P.: Estimation of carbon allocation to the roots from soil respiration measurements of oil palm, Plant Soil, 181, 329-339, 1996.

Lane, R. W., Menon, M., McQuaid, J. B., Adams, D. G., Thomas, A. D., Hoon, S. R., and Dougill, A. J.: Laboratory analysis of the effects of elevated atmospheric carbon dioxide on respiration in biological soil crusts, J. Arid Environ., 98, 52-59, 2013.

Lee, K.-H. and Jose, S.: Soil respiration and microbial biomass in a pecan-cotton alley cropping system in southern USA, Agroforest. Syst., 58, 45-54, 2003.

Linquist, B. A., Adviento-Borbe, M. A., Pittelkow, C. M., van Kessel, C., and van Groenigen, K. J.: Fertilizer management practices and greenhouse gas emissions from rice systems: A quantitative review and analysis, Field Crops Res., 135, 10-21, 2012.

Lompo, D. J.-P., Sangaré, S. A. K., Compaoré, E., Papoada Sedogo, M., Predotova, M., Schlecht, E., and Buerkert, A.: Gaseous emissions of nitrogen and carbon from urban vegetable gardens in bobo-dioulasso, Burkina Faso, J. Plant Nutr. Soil Sci., 175, 846853, 2012.

Macdonald, J. A., Eggleton, P., Bignell, D. E., Forzi, F., and Fowler, D.: Methane emission by termites and oxidation by soils, across a forest disturbance gradient in the mbalmayo forest reserve, Cameroon, Glob. Change Biol., 4, 409-418, 1998.

Mafongoya, P., Giller, K., and Palm, C.: Decomposition and nitrogen release patterns of tree prunings and litter, Agroforest. Syst., 38, 77-97, 1997.

Makumba, W., Akinnifesi, F. K., Janssen, B., and Oenema, O.: Long-term impact of a gliricidia-maize intercropping system on carbon sequestration in southern Malawi, Agr. Ecosyst. Environ., 118, 237-243, 2007.

Malhi, S., Nyborg, M., Solberg, E., Dyck, M., and Puurveen, D.: Improving crop yield and $\mathrm{N}$ uptake with long-term straw retention in two contrasting soil types, Field Crops Res., 124, 378-391, 2011.

Mann, P. J., Spencer, R. G., Dinga, B., Poulsen, J. R., Hernes, P., Fiske, G., Salter, M. E., Wang, Z. A., Hoering, K. A., and Six, J.: The biogeochemistry of carbon across a gradient of streams and rivers within the Congo basin, J. Geophys. Res.-Biogeo., 119, 687-702, 2014.

Mapanda, F., Mupini, J., Wuta, M., Nyamangara, J., and Rees, R.: A cross-ecosystem assessment of the effects of land cover and land use on soil emission of selected greenhouse gases and related soil properties in Zimbabwe, Eur. J. Soil Sci., 61, 721-733, 2010.

Mapanda, F., Wuta, M., Nyamangara, J., and Rees, R. M.: Effects of organic and mineral fertilizer nitrogen on greenhouse gas emissions and plant-captured carbon under maize cropping in Zimbabwe, Plant Soil, 343, 67-81, 2011.

Mapanda, P., Wuta, M., Nyamangara, J., Rees, R., and Kitzler, B.: Greenhouse gas emissions from savanna (miombo) woodlands: Responses to clearing and cropping, Afr. Crop Sci. J., 20, 385400, 2012.

Masaka, J., Nyamangara, J., and Wuta, M.: Nitrous oxide emissions from wetland soil amended with inorganic and organic fertilizers, Arch. Agron. Soil Sci., 60, 1363-1387, 2014.

Merbold, L., Ziegler, W., Mukelabai, M. M., and Kutsch, W. L.: Spatial and temporal variation of $\mathrm{CO}_{2}$ efflux along a disturbance gradient in a miombo woodland in Western Zambia, Biogeosciences, 8, 147-164, doi:10.5194/bg-8-147-2011, 2011.

Millar, N. and Baggs, E. M.: Chemical composition, or quality, of agroforestry residues influences $\mathrm{N}_{2} \mathrm{O}$ emissions after their addition to soil, Soil Biol. Biochem., 36, 935-943, 2004.

Millar, N. and Baggs, E. M.: Relationships between $\mathrm{N}_{2} \mathrm{O}$ emissions and water-soluble $\mathrm{c}$ and $\mathrm{n}$ contents of agroforestry residues after their addition to soil, Soil Biol. Biochem., 37, 605-608, 2005.

Millar, N., Ndufa, J., Cadisch, G., and Baggs, E.: Nitrous oxide emissions following incorporation of improved-fallow residues in the humid tropics, Global Biogeochem. Cy., 18, GB1032, doi:doi:10.1029/2003GB002114, 2004.

Motulsky, H. J. and Christopoulos, A.: Fitting models to biological data using linear and nonlinear regression: a practical guide to curve fitting, Oxford University Press, New York, 2004.

Nouvellon, Y., Epron, D., Marsden, C., Kinana, A., Le Maire, G., Deleporte, P., Saint-André L., Bouillet, J.-P., and Laclau, J.-P.: Age-related changes in litter inputs explain annual trends in soil $\mathrm{CO}_{2}$ effluxes over a full eucalyptus rotation after afforestation of a tropical savannah, Biogeochemistry, 111, 515-533, 2012.

Nyamadzawo, G., Gotosa, J., Muvengwi, J., Wuta, M., Nyamangara, J., Nyamugafata, P., and Smith, J. L.: The effect of catena position on greenhouse gas emissions from dambo located termite (odontotermes transvaalensis) mounds from central Zimbabwe, Atmos. Climate Sci., 2, 501-509, doi:10.4236/acs.2012.24044, 2012.

Nyamadzawo, G., Wuta, M., Chirinda, N., Mujuru, L., and Smith, J. L.: Greenhouse gas emissions from intermittently flooded (dambo) rice under different tillage practices in chiota smallholder farming area of Zimbabwe, Atmos. Climate Sci., 3, 1320, 2013.

Nyamadzawo, G., Wuta, M., Nyamangara, J., Smith, J. L., and Rees, R. M.: Nitrous oxide and methane emissions from cultivated seasonal wetland (dambo) soils with inorganic, organic and integrated nutrient management, Nutr. Cycl. Agroecosys., 100, 161175, 2014a.

Nyamadzawo, G., Shi, Y., Chirinda, N., Olesen, J. R., Mapanda, F., Wuta, M., Wu, W., Meng, F., Oelofse, M., de Neergaard, A., and Smith, J.: Combining organic and inorganic nitrogen fertilisation reduces $\mathrm{N}_{2} \mathrm{O}$ emissions from cereal crops: a comparative analysis of China and Zimbabwe, Mitig. Adapt. Strategies Glob. Chang., 1-13, doi:10.1007/s11027-014-9560-9, 2014b.

Olander, L., Wollenberg, E., Tubiello, F., and Herold, M.: Advancing agricultural greenhouse gas quantification, Environ. Res. Lett., 8, 011002, doi:10.1088/1748-9326/8/1/011002, 2013.

Palm, C. A., Smukler, S. M., Sullivan, C. C., Mutuo, P. K., Nyadzi, G. I., and Walsh, M. G.: Identifying potential synergies and tradeoffs for meeting food security and climate change objectives in sub-Saharan Africa, P. Natl. Acad. Sci. USA, 107, 19661-19666, 2010.

Parkin, T. B.: Effect of sampling frequency on estimates of cumulative nitrous oxide emissions, J. Environ. Qual., 37, 1390-1395, 2008.

Pelster, D. E., Chantigny, M. H., Rochette, P., Angers, D. A., Rieux, C., and Vanasse, A.: Nitrous oxide emissions respond differently to mineral and organic $\mathrm{N}$ sources in contrasting soil types, J. Environ. Qual., 41, 427-435, 2012. 
Philibert, A., Loyce, C., and Makowski, D.: Quantifying uncertainties in $\mathrm{N} 2 \mathrm{O}$ emission due to $\mathrm{N}$ fertilizer application in cultivated areas, PLoS ONE, 7, e50950, 2012.

Predotova, M., Schlecht, E., and Buerkert, A.: Nitrogen and carbon losses from dung storage in urban gardens of Niamey, Niger, Nutr. Cycl. Agroecosys., 87, 103-114, 2010.

Priemé, A. and Christensen, S.: Methane uptake by a selection of soils in Ghana with different land use, J. Geophys. Res., 104, 23617-23622, 1999.

Rabenarivo, M., Wrage-Moennig, N., Chotte, J. L., Rabeharisoa, L., Razafimbelo, T. M., and Chapuis-Lardy, L.: Emissions of $\mathrm{CO}_{2}$ and $\mathrm{N}_{2} \mathrm{O}$ from a pasture soil from Madagascar-simulating conversion to direct-seeding mulch-based cropping in incubations with organic and inorganic inputs, J. Plant Nutr. Soil Sci., 177, 360-368, 2014.

Raich, J. and Schlesinger, W.: The global carbon dioxide flux in soil respiration and its relationship to vegetation and climate, Tellus B, 44, 81-99, 1992.

Reed, D. E., Ewers, B. E., and Pendall, E.: Impact of mountain pine beetle induced mortality on forest carbon and water fluxes, Environ. Res. Lett., 9, 105004, doi:10.1088/1748-9326/9/10/105004, 2014.

Rees, R. M., Wuta, M., Furley, P. A., and Li, C.: Nitrous oxide fluxes from savanna (miombo) woodlands in Zimbabwe, J. Biogeogr., 33, 424-437, 2006.

Rezaei Rashti, M., Wang, W., Moody, P., Chen, C., and Ghadiri, H.: Fertiliser-induced nitrous oxide emissions from vegetable production in the world and the regulating factors: A review, Atmos. Environ., 112, 225-233, 2015.

Rochette, P. and Eriksen-Hamel, N. S.: Chamber measurements of soil nitrous oxide flux: Are absolute values reliable?, Soil Sci. Soc. Am. J., 72, 331-342, doi:10.2136/sssaj2007.0215, 2008.

Rosenstock, T., Rufino, M., Butterbach-Bahl, K., and Wollenberg, E.: Toward a protocol for quantifying the greenhouse gas balance and identifying mitigation options in smallholder farming systems, Environ. Res. Lett., 8, 021003, doi:10.1088/17489326/8/2/021003, 2013.

Rosenstock, T. S., Diaz-Pines, E., Zuazo, P., Jordan, G., Predotova, M., Mutuo, P., Abwanda, S., Thiong'o, M., Buerkert, A., Rufino, M. C., Kiese, R., Neufeldt, H., and Butterbach-Bahl, K.: Accuracy and precision of photoacoustic spectroscopy not guaranteed, Glob. Change Biol., 19, 3565-3567, doi:10.1111/gcb.12332, 2013

Rosenstock, T. S., Mathew, M., Pelster, D. E., Butterbach-Bahl, K., Rufino, M. C., Thiong'o, M., Mutuo, P., Abwanda, S., Rioux, J., Kimaro, A. A., and Neufeldt, H. C. J. G.: Greenhouse gas fluxes from agricultural soils of Kenya and Tanzania, J. Geophys. Res., 121, 1568-1580, doi:10.1002/2016JG003341, 2016.

Saggar, S., Jha, N., Deslippe, J., Bolan, N. S., Luo, J., Giltrap, D. L., Kim, D. G., Zaman, M., and Tillman, R. W.: Denitrification and $\mathrm{N}_{2} \mathrm{O}: \mathrm{N}_{2}$ production in temperate grasslands: Processes, measurements, modelling and mitigating negative impacts, Sci. Total Environ., 465, 173-195, 2013.

Shcherbak, I., Millar, N., and Robertson, G. P.: Global metaanalysis of the nonlinear response of soil nitrous oxide $\left(\mathrm{N}_{2} \mathrm{O}\right)$ emissions to fertilizer nitrogen, P. Natl. Acad. Sci. USA, 111, 9199-9204, 2014.
Sheehy, J., Six, J., Alakukku, L., and Regina, K.: Fluxes of nitrous oxide in tilled and no-tilled boreal arable soils, Agr. Ecosyst. Environ., 164, 190-199, 2013.

Smith, D. L. and Johnson, L.: Vegetation-mediated changes in microclimate reduce soil respiration as woodlands expand into grasslands, Ecology, 85, 3348-3361, 2004.

Smith, K.: Nitrous Oxide and Climate Change, Earthscan, London, UK, 240 pp., 2010.

Snyder, C. S., Bruulsema, T. W., Jensen, T. L., and Fixen, P. E.: Review of greenhouse gas emissions from crop production systems and fertilizer management effects, Agr. Ecosyst. Environ., 133, 247-266, 2009.

Sommer, R., Mukalama, J., Kihara, J., Koala, S., Winowiecki, L., and Bossio, D.: Nitrogen dynamics and nitrous oxide emissions in a long-term trial on integrated soil fertility management in western Kenya, Nutr. Cycl. Agroecosys., 105, 229-248, doi:10.1007/s10705-015-9693-6, 2015.

Stringer, L., Dougill, A. J., Thomas, A. D., Spracklen, D., Chesterman, S., Speranza, C. I., Rueff, H., Riddell, M., Williams, M., and Beedy, T.: Challenges and opportunities in linking carbon sequestration, livelihoods and ecosystem service provision in drylands, Environ. Sci. Policy, 19, 121-135, 2012.

Sugihara, S., Funakawa, S., Kilasara, M., and Kosaki, T.: Effects of land management on $\mathrm{CO}_{2}$ flux and soil $\mathrm{C}$ stock in two Tanzanian croplands with contrasting soil texture, Soil Biol. Biochem., 46, $1-9,2012$.

Tathy, J., Cros, B., Delmas, R., Marenco, A., Servant, J., and Labat, M.: Methane emission from flooded forest in central Africa, J. Geophys. Res., 97, 6159-6168, 1992.

Teodoru, C. R., Nyoni, F. C., Borges, A. V., Darchambeau, F., Nyambe, I., and Bouillon, S.: Dynamics of greenhouse gases $\left(\mathrm{CO}_{2}, \mathrm{CH}_{4}, \mathrm{~N}_{2} \mathrm{O}\right)$ along the Zambezi River and major tributaries, and their importance in the riverine carbon budget, Biogeosciences, 12, 2431-2453, doi:10.5194/bg-12-2431-2015, 2015.

Thauer, R.: Biochemistry of methanogenesis: A tribute to marjory stephenson, Microbiology, 144, 2377-2406, 1998.

Thomas, A. D.: Impact of grazing intensity on seasonal variations in soil organic carbon and soil $\mathrm{CO}_{2}$ efflux in two semiarid grasslands in southern Botswana, Philos. T. R. Soc. B., 367, 30763086, 2012.

Thomas, A. D., Hoon, S. R., and Dougill, A. J.: Soil respiration at five sites along the kalahari transect: Effects of temperature, precipitation pulses and biological soil crust cover, Geoderma, 167, 284-294, 2011.

Thomas, A. D., Dougill, A. J., Elliott, D. R., and Mairs, H.: Seasonal differences in soil $\mathrm{CO}_{2}$ efflux and carbon storage in Ntwetwe pan, Makgadikgadi Basin, Botswana, Geoderma, 219, 72-81, 2014.

Thompson, R. L., Chevallier, F., Crotwell, A. M., Dutton, G., Langenfelds, R. L., Prinn, R. G., Weiss, R. F., Tohjima, Y., Nakazawa, T., Krummel, P. B., Steele, L. P., Fraser, P., O'Doherty, S., Ishijima, K., and Aoki, S.: Nitrous oxide emissions 1999 to 2009 from a global atmospheric inversion, Atmos. Chem. Phys., 14, 1801-1817, doi:10.5194/acp-14-18012014, 2014.

Tubiello, F. N., Salvatore, M., Rossi, S., Ferrara, A., Fitton, N., and Smith, P.: The FAOSTAT database of greenhouse gas emissions from agriculture, Environ. Res. Lett., 8, 015009, doi:10.1088/1748-9326/8/1/015009, 2013. 
Tubiello, F. N., Salvatore, M., Ferrara, A. F., House, J., Federici, S., Rossi, S., Biancalani, R., Condor Golec, R. D., Jacobs, H., Flammini, A., Prosperi, P., Cardenas-Galindo, P., Schmidhuber, J., Sanz Sanchez, M. J., Srivastava, N., and Smith, P.: The contribution of agriculture, forestry and other land use activities to global warming, 1990-2012, Glob. Change Biol., 21, 2655-2660, 2015.

Tufekcioglu, A., Raich, J., Isenhart, T., and Schultz, R.: Soil respiration within riparian buffers and adjacent crop fields, Plant Soil, 229, 117-124, 2001

Tyler, S. C., Zimmerman, P. R., Cumberbatch, C., Greenberg, J. P., Westberg, C., and Darlington, J. P.: Measurements and interpretation of $\delta^{13} \mathrm{C}$ of methane from termites, rice paddies, and wetlands in Kenya, Global Biogeochem. Cy., 2, 341-355, 1988.

US EPA: Draft US Greenhouse Gas Inventory Report: 19902014, available at: https://www3.epa.gov/climatechange/ ghgemissions/usinventoryreport.html, last access: 10 April 2016.

Valentini, R., Arneth, A., Bombelli, A., Castaldi, S., Cazzolla Gatti, R., Chevallier, F., Ciais, P., Grieco, E., Hartmann, J., Henry, M., Houghton, R. A., Jung, M., Kutsch, W. L., Malhi, Y., Mayorga, E., Merbold, L., Murray-Tortarolo, G., Papale, D., Peylin, P., Poulter, B., Raymond, P. A., Santini, M., Sitch, S., Vaglio Laurin, G., van der Werf, G. R., Williams, C. A., and Scholes, R. J.: A full greenhouse gases budget of Africa: synthesis, uncertainties, and vulnerabilities, Biogeosciences, 11, 381-407, doi:10.5194/bg11-381-2014, 2014.

Van Groenigen, J., Velthof, G., Oenema, O., Van Groenigen, K., and Van Kessel, C.: Towards an agronomic assessment of $\mathrm{N}_{2} \mathrm{O}$ emissions: A case study for arable crops, Eur. J. Soil Sci., 61, 903-913, 2010.

Vargas, R.: How a hurricane disturbance influences extreme $\mathrm{CO}_{2}$ fluxes and variance in a tropical forest, Environ. Res. Lett., 7, 035704, doi:10.1088/1748-9326/7/3/035704, 2012.

Verchot, L. V., Brienza Junior, S., de Oliveira, V. C., Mutegi, J. K., Cattanio, J. H., and Davidson, E. A.: Fluxes of $\mathrm{CH}_{4}, \mathrm{CO}_{2}, \mathrm{NO}$, and $\mathrm{N}_{2} \mathrm{O}$ in an improved fallow agroforestry system in eastern Amazonia, Agr. Ecosyst. Environ., 126, 113-121, 2008.

Wang, Z. A., Bienvenu, D. J., Mann, P. J., Hoering, K. A., Poulsen, J. R., Spencer, R. G., and Holmes, R. M.: Inorganic carbon speciation and fluxes in the Congo River, Geophys. Res. Lett., 40, 511-516, 2013.
Werner, C., Kiese, R., and Butterbach-Bahl, K.: Soil-atmosphere exchange of $\mathrm{N}_{2} \mathrm{O}, \mathrm{CH}_{4}$, and $\mathrm{CO}_{2}$ and controlling environmental factors for tropical rain forest sites in western Kenya, J. Geophys. Res., 112, D03308, doi:10.1029/2006JD007388, 2007.

Wrage, N., Velthof, G. L., van Beusichem, M. L., and Oenema, O.: Role of nitrifier denitrification in the production of nitrous oxide, Soil Biol. Biochem., 33, 1723-1732, 2001.

Yang, J., Liu, J., Hu, X., Li, X., Wang, Y., and Li, H.: Effect of water table level on $\mathrm{CO}_{2}, \mathrm{CH}_{4}$ and $\mathrm{N}_{2} \mathrm{O}$ emissions in a freshwater marsh of Northeast China, Soil Biol. Biochem., 61, 52-60, 2013.

Yashiro, Y., Kadir, W. R., Okuda, T., and Koizumi, H.: The effects of logging on soil greenhouse gas $\left(\mathrm{CO}_{2}, \mathrm{CH}_{4}, \mathrm{~N}_{2} \mathrm{O}\right)$ flux in a tropical rain forest, Peninsular Malaysia, Agr. Forest. Meteorol., 148, 799-806, 2008.

Yohannes, Y., Shibistova, O., Abate, A., Fetene, M., and Guggenberger, G.: Soil $\mathrm{CO}_{2}$ efflux in an afromontane forest of ethiopia as driven by seasonality and tree species, Forest Ecol. Manage., 261, 1090-1098, doi:10.4172/2168-9776.1000111, 2011.

Yohannes, Y., Shibistova, O., Asaye, Z., and Guggenberger, G.: Forest management influence on the carbon flux of cupressus lusitanica plantation in the Munessa forest, Ethiopia, Forest Res., 2, 111, doi:10.4172/2168-9776.1000111, 2013.

Zepp, R. G., Miller, W. L., Burke, R. A., Parsons, D. A. B., and Scholes, M. C.: Effects of moisture and burning on soil-atmosphere exchange of trace carbon gases in a southern African savanna, J. Geophys. Res., 101, 23699-23706, 1996.

Zomer, R. J., Trabucco, A., Coe, R., and Place, F.: Trees on farm: analysis of global extent and geographical patterns of agroforestry, ICRAF Working Paper No. 89, (World Agroforestry Centre (ICRAF), 2009), http://www.worldagroforestry. org/downloads/Publications/PDFs/WP16263.PDF, last access: 18 August 2016. 